\title{
Chapter
}

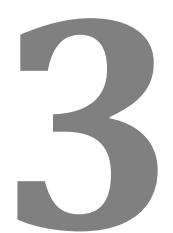

\section{ANTIMICROBIAL RESISTANCE IN STAPHYLOCOCCI}

\section{Monika Pipová}

University of Veterinary Medicine and Pharmacy in Košice, Komenského 73, 04181 Košice, Slovak Republic 


\section{Contents}

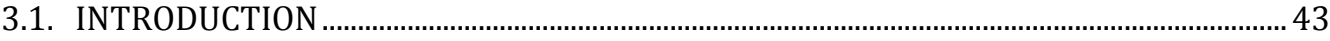

3.2. CHARACTERISTICS OF THE GENUS STAPHYLOCOCCUS .................................................... 45

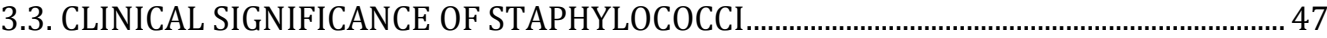

3.4. MECHANISMS OF ANTIMICROBIAL RESISTANCE IN STAPHYLOCOCCI ........................... 50

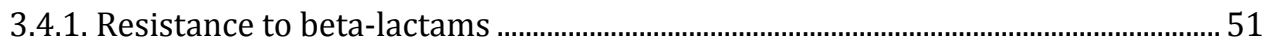

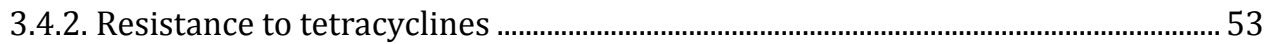

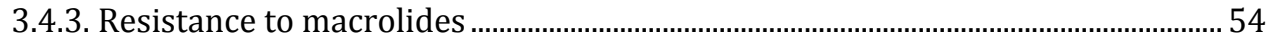

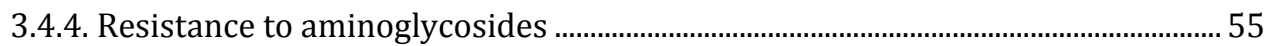

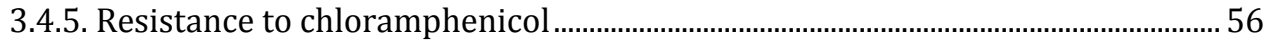

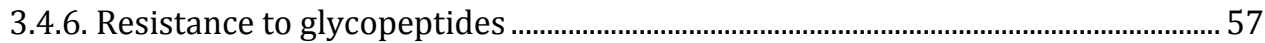

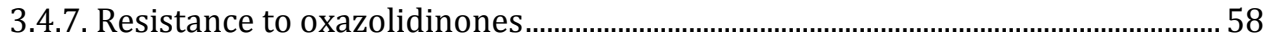

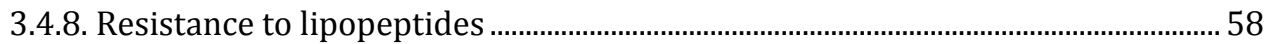

3.5. METHICILLIN-RESISTANT STAPHYLOCOCCUS AUREUS (MRSA) ….................................... 59

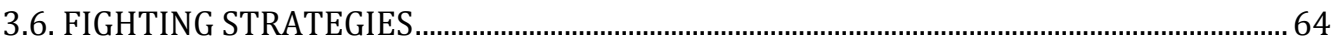

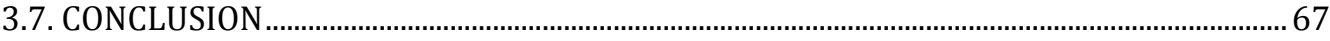

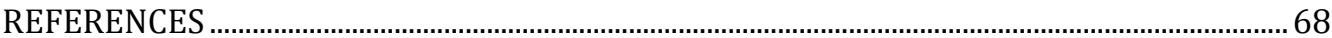




\subsection{INTRODUCTION}

Staphylococci are wide-spread commensal bacteria that colonise the skin and mucous membranes of humans and animals. The presence of numerous virulence factors makes these bacteria opportunistic pathogens [1], which, under suitable conditions, may become harmful to the host.

Pathogenicity was first only attributed to coagulase-positive staphylococci (CoPS). Recently, this opinion has changed because of the discovery of virulence genes among coagulase-negative staphylococci (CoNS). Moreover, CoNS are seen as potential donors of resistance genes for not only closely related bacterial genera. A particularly serious problem is the transfer of resistance genes between CoNS and human or animal pathogens. It has to be realised that CoNS could significantly increase the pathogenic potential of other bacteria and, via the transfer of resistance genes, may decrease the possibilities of disease control because of treatment failure.

The discovery of penicillin in 1928 by the Scottish scientist Sir Alexander Fleming has marked a new era in the treatment of staphylococcal infections in both human and veterinary medicine. The production and application of antibiotics have increased within a few of years to such an extent that the twentieth century could be referred to as "the century of antibiotics".

However, the miracle of antibiotics soon collapsed with the emergence of the first resistant bacterial strains. Staphylococci have begun to develop effective mechanisms to eliminate the lethal power of antibiotics. Upon permanent contact with antibiotics, these bacteria activated their defence mechanisms and changed their metabolic pathways to win this fight against humankind. Staphylococci are able to persist under extreme environmental conditions for a long time, as evidenced by the recovery of two Staphylococcus succinus strains from 25-35-million-year-old Dominican amber [2]. Because of their extreme adaptability, it is practically impossible to eliminate staphylococci from the environment. Therefore, these bacteria have to be acknowledged, tolerated and understood to be able to predict their behaviour and to minimise the risk for humans and animals.

The phenomenon of antimicrobial resistance can affect any country of the world. Mechanisms of antimicrobial resistance can spread globally among microbial species and genera and are not fully understood. Nowadays, resistant strains of staphylococci can be found in the environment, in animals, humans and various food products. Therefore, the dissemination of resistance genes poses a challenge for both human and animal health professionals [3]. Across the globe, microbiologists and pharmacologists investigate the microbial mechanisms of drug inactivation and synthesise new generations of antibiotics in an attempt to control bacterial infections. However, it is more 
than likely that staphylococci will soon develop other effective tools to fight the new drugs, thereby repeating the cycle.

In the last decades, the emergence of the methicillin-resistant Staphylococcus aureus (MRSA) and Staphylococcus epidermidis (MRSE) has been a major concern. Patients with infections caused by resistant microbial strains are at higher risk of death than patients infected with non-resistant strains of the same bacteria. As reported by the World Health Organization, people infected with MRSA are estimated to be $64 \%$ more likely to die than people with a nonresistant form of the infection [4]. Hospital-acquired and health-care related infections caused by multidrug-resistant strains of staphylococci require longer hospital stays and higher costs for medical treatment, with increased mortality and decreased effects of the antimicrobial therapy. Permanent increase in antimicrobial resistance leads us to the conclusion that the twentyfirst century will probably be referred to as "the century of antimicrobial resistance".

Currently, the food chain is seen as one the most important pathways of spreading antimicrobial resistance. Sufficient heat treatment of processed food products will stop the activity of vegetative bacterial cells. However, pasteurisation temperatures destroy neither bacterial DNA nor mobile genetic elements encoding antimicrobial resistance. Although the vegetative cells are devitalised, the resistance genes remain in a particular food product. After consumption, these genes can be incorporated into the genome of other viable bacteria in the digestive tract of the host.

The occurrence of resistant staphylococci in drinking water and wastewaters may also represent a hazard, particularly under conditions capable of favouring their overgrowth [5]. Municipal wastewaters can also serve as reservoirs for MRSA dissemination [6]. If wastewater treatment methods will not be changed soon, resistance genes present in the effluents from hospitals and animal slaughterhouses will continue to persist in the environment. Resistant CoNS strains have also been found in free-living animals. These animals move throughout the environment without any boundaries and can therefore easily come into contact with agricultural and municipal wastes as well as food-producing animals and pets, making them potential reservoirs for resistance genes. The presence of genes encoding antimicrobial resistance is no always accompanied with their phenotypic expression, as some genes may remain dormant. Therefore, phenotypic susceptibility is a better criterion when considering treatment options [7].

The problem of antimicrobial resistance requires an international approach of all participants, including politicians, health professionals, farmers, health-care and food industry experts, as well as all members of the society. There is a general need develop new, effective fighting strategies based on prevention via national action plans developed by individual countries, surveillance of infections caused by resistant strains, effective control measures, investments 
in the development of new medicines and diagnostics tools as well as permanent information of the public on the impact of antibiotic resistance. Antimicrobial resistance is a problem of global public health and food security and requires coordinated efforts from all countries.

\subsection{CHARACTERISTICS OF THE GENUS STAPHYLOCOCCUS}

Staphylococci are ubiquitous Gram-positive, spherical, nonmotile bacteria that can be found on the skin and mucous membranes of warm-blooded animals and humans, in environmental resources (e.g. air, soil, sand, dust or natural waters), as well as in various food products such as milk, meat or cheese [1]. Due to the typical structure of their cell wall, which comprises peptidoglycan and teichoic acid, staphylococci are highly tolerant to drying and dehydration [8].

Based on comparative 16S rRNA sequence analysis, the genus Staphylococcus belongs to the phylum Firmicutes, class Bacilli, order Bacillales and family Staphylococcaceae [1]. Currently, more than 50 species and almost 30 subspecies are recognised among staphylococci. The three most recent species, described in 2015, include S. argensis [9], S. argenteus and $S$. schweitzeri [10]. Most strains of staphylococci are catalase-positive and oxidase-negative, grow at temperatures between 18 and $40{ }^{\circ} \mathrm{C}$ and tolerate the presence of $10 \% \mathrm{NaCl}$. In general, staphylococci are resistant to lysis by lysozyme, low levels of erythromycin and bacitracin, but susceptible to furazolidone, nitrofuran and lysis by lysostaphin [1].

According to plasma coagulation, staphylococci are classified as coagulasepositive staphylococci (CoPS) or coagulase-negative staphylococci (CoNS). Coagulase is an enzyme that reacts with prothrombin in the blood. The resulting staphylothrombin complex enables the enzyme protease to convert fibrinogen to fibrin, resulting in blood clot formation. Two types of coagulase are recognised in staphylococci, bound coagulase and free coagulase. While free coagulase is a heat-labile enzyme that is secreted extracellularly, bound coagulase is a cell wall-associated protein. Free coagulase binds with coagulase-reacting factor (CRF) in the blood and forms the complex staphylothrombin. Bound coagulase is also known as clumping factor. Upon contact with blood, the fibrin cloth protects the bacterium from phagocytosis and other host defence mechanisms [11]. Most human $S$. aureus isolates possess both forms of coagulase $[12,13]$.

The formation of the coagulase enzyme is encoded by the coa gene, which is highly polymorphic [14]. Detailed gene analysis has revealed variable sequences in the 3 '-end coding region of allelic gene forms [15], particularly in the $\mathrm{C}$-terminal region containing the $81 \mathrm{bp}$ tandem short sequence repeats 
(SSRs) encoding repeated 27 amino acid sequences [14,16]. Therefore, various sizes of coa gene have been observed and reported [17-19]. Because of a close correlation between coagulase formation and the pathogenicity of staphylococci, detecting the coagulase enzyme is still of great clinical importance $[14,20]$.

Table 1. Species groups of staphylococci with clinical significance

\begin{tabular}{|c|c|c|}
\hline & Species group & Species (subspecies) \\
\hline \multirow{5}{*}{$\begin{array}{l}\text { Coagulase-positive and } \\
\text { novobiocin-susceptible }\end{array}$} & Staphylococcus intermedius & S. delphini \\
\hline & & S. intermedius \\
\hline & & S. pseudintermedius \\
\hline & & S. schleiferi subsp. coagulans \\
\hline & S. aureus & S. aureus \\
\hline \multirow{12}{*}{$\begin{array}{l}\text { Coagulase-negative and } \\
\text { novobiocin-susceptible }\end{array}$} & Staphylococcus epidermidis & S. capitis \\
\hline & & S. caprae \\
\hline & & S. epidermidis \\
\hline & & S. haemolyticus \\
\hline & & S. hominis \\
\hline & & S. saccharolyticus \\
\hline & & S. schleiferi subsp. schleiferi \\
\hline & & S. simiae \\
\hline & & S. warneri \\
\hline & Staphylococcus simulans & S. carnosus \\
\hline & ( $\beta$-galactosidase-positive) & S. felis \\
\hline & & S. simulans \\
\hline \multirow{13}{*}{$\begin{array}{l}\text { Coagulase-negative and } \\
\text { novobiocin-resistant }\end{array}$} & Staphylococcus saprophyticus & S. arlettee \\
\hline & & S. cohnii \\
\hline & & S. equorum \\
\hline & & S. galinarum \\
\hline & & S. kloosii \\
\hline & & S. neaplensis \\
\hline & & S. saprohyticus \\
\hline & & S. succinus \\
\hline & & S. xylosus \\
\hline & Staphylococcus sciuri & S. lentus \\
\hline & (oxidase-positive) & S. sciuri \\
\hline & & S. vitulinus \\
\hline & & S. fleurettii \\
\hline \multirow{2}{*}{$\begin{array}{c}\text { Coagulase-variable and } \\
\text { novobiocin-resistant }\end{array}$} & & S. chromogenes \\
\hline & & S. hyicus \\
\hline
\end{tabular}

Staphylococcus aureus possess a long list of virulence factors. These include surface proteins necessary for colonisation and secreted proteins that allow invasion of and damage to host cells and tissues. Surface proteins include clumping factor, protein A, capsular polysaccharide adhesin as well as 
fibronectin- and collagen-binding proteins. Secreted are numerous toxins $(\alpha-, \beta-, \gamma-$ and $\delta$-toxins, exfoliate toxins, enterotoxins, toxic shock syndrome toxin, Panton-Valentine leukocidin) and various enzymes (catalase, deoxyribonuclease, hyaluronidase, $\beta$-lactamase, staphylokinase, lipases) [21,22].

Based on DNA-DNA hybridisation studies, staphylococci have been divided into several species groups [8]. Individual species (subspecies) with clinical significance are shown in Table 1.

\subsection{CLINICAL SIGNIFICANCE OF STAPHYLOCOCCI}

Virulence factors are mostly associated with coagulase-positive staphylococci. Among them, $S$. aureus is the most significant human pathogen responsible for a variety of respiratory, wound, skin and soft tissue infections, such as pneumonia, folliculitis, furuncles, carbuncles, impetigo, myocarditis, pericarditis, acute endocarditis, osteomyelitis, enterocolitis, mastitis, cystitis, prostatitis, cervicitis, meningitis or bacteraemia [1]. The main constituents of the cell wall of $S$. aureus are peptidoglycan, teichoic acid, fibronectin-binding proteins, clumping factor and collagen-binding proteins. S. aureus is a pyogenic bacterium capable of inducing abscess formation in the skin, muscles, urogenital tract, central nervous system and internal organs. Predisposing factors for skin and soft tissue infections include skin damage, skin disease, injections and poor personal hygiene. In the last decades, S. aureus has been confirmed as one of the leading causes of hospital-acquired (nosocomial) and community-acquired infections [23].

Toxin-mediated $S$. aureus diseases include the scalded-skin syndrome, toxic shock syndrome and food-borne enterotoxicosis. In each of those diseases, toxins act as "superantigens" and cause the release of large amounts of inflammatory mediators, resulting in fever, rash and hypotension [23].

Staphylococcal scalded-skin syndrome (SSSS) affects most frequently newborns and children, causing remarkable blistering on the superficial skin surface caused by exfoliative toxins released by $S$. aureus [24], known as the two epidermolytic exotoxins A and B $[25,26]$. The disease is manifested by the formation of watery red blisters on the skin, resulting in a scaled or burned appearance. This infection may lead to the exfoliation of most of the skin surface, followed by acute erythematous cellulitis [27].

Toxic shock syndrome (TSS) has first been described in children [28]. Subsequently, TSS has been associated with the use of super-absorbent tampons by menstruating women [29]. It is caused by the production of toxic shock syndrome toxin (TSST-1) and occurs 2-3 days after the onset of the menses, usually without any evidence of other illnesses. In addition to fever 
and hypotension, the disease is typically manifested by a diffuse macular rash on the palms and the soles, with subsequent desquamation (1-2 weeks after disease onset) and multisystem involvement [23].

Enterotoxigenic strains of $S$. aureus are involved into outbreaks of the most prevalent food-borne intoxication, known as staphylococcal enterotoxicosis. The food poisoning is attributed to the ingestion of heat-stable staphylococcal exotoxins; 22 types of staphylococcal enterotoxins $(A-V)$ are currently known $[30,31]$. The disease onset is rapid (1-6 hrs after ingestion of contaminated food) and explosive, fever is absent [23]. The main clinical signs include nausea, abdominal pain, cramps, vomiting and headache. Symptoms resolve spontaneously within 24-48 hours [32].

To avoid the risk of staphylococcal enterotoxicosis and to protect the health of consumers, food business operators need to ensure that foodstuffs comply with the relevant microbiological criteria set out in Commission Regulation No $2073 / 2005$. Food safety criteria define the acceptability of a product or a batch of food products to be placed on the market. In terms of the above-mentioned regulation, a batch of cheeses (particularly those made of raw, unpasteurised milk) has to be tested for the presence of enterotoxins if the numbers of coagulase-positive staphylococci exceed the limit of $10^{5} \mathrm{CFU} \mathrm{g}^{-1}$ [33]. Enterotoxins can be produced by viable cells of staphylococci, albeit only at suitable temperatures. Therefore, the maintenance of the cold chain during production, storage and retail sale of finished food products is crucial to ensure food security [34].

The most common $S$. aureus infections in mammals and birds include clinical or subclinical mastitis, suppurative dermatitis, endometritis, synovitis, arthritis, dermatitis, furuncles, pyemia and septicaemia [1]. S. aureus subsp. anaerobius has been recognised as the causal agent of "abscess disease” in sheep, with clinical symptoms similar to those of caseous lymphadenitis [35].

Human infections with coagulase-positive staphylococci other than $S$. aureus are rare. There are no published cases of $S$. delphini infections in humans [36]. Foissac et al. [37] have documented the case of spondylodiscitis and bacteremia caused by $S$. hyicus in an immunocompetent patient. So far, four cases of human $S$. intermedius infections have been identified, three cases were soft tissue and/or bone infections and one case was a urinary tract infection [38]. The first human case of $S$. intermedius infection of a mechanical prosthesis has been reported by Wang et al. [36]; the presumed source of infection was the patient's dog. Dog ownership, as well as diabetes or immunosuppression, may place patients at higher risk [38].

Among zoonotic pathogens, $S$. intermedius is the predominant cause of skin and soft tissue infections in dogs and human infections associated with bite wounds $[39,40]$. However, there is no true incidence of $S$. intermedius and $S$. pseudintermedius infections, as these species are frequently misidentified as $S$. aureus [36]. Staphylococcus schleiferi subsp. coagulans has been isolated from 
the external auditory meatus of dogs suffering from external otitis [41]; $S$. delphini has been detected in purulent material taken from two dolphins living in an aquarium [42]. The coagulase-variable S. hyicus has been identified as the causative agent of skin lesions, osteomyelitis and occasional bovine mastitis [43], skin lesions ("grease heel") in horses [44], osteomyelitis in poultry [45], septic polyarthritis [46], porcine infectious epidermitis, also known as "greasy pig disease" [47], and reproductive failure in sows [48].

The CoNS are major components of the skin, oropharyngeal and vaginal microflora. These species are reported as less virulent than $S$. aureus. However, numerous studies have revealed the presence of some virulence factors among CoNS [49-52], including their ability to produce heat-stable enterotoxins $[53,54]$. Some CoNS species are capable of causing serious human diseases and nosocomial infections. Primarily, species of CoNS are important and common causes of prosthetic-device infections. As reported, up to $5 \%$ of native-valve endocarditis cases have been due to CoNS [23]. In such cases, the most important property of coagulase-negative staphylococci is their ability to form a biofilm on the surfaces of foreign bodies introduced (implanted) into the organism as a protection against the effects of antibacterial drugs and the immune system of the host [55].

The greatest pathogenic potential has been reported for $S$. epidermidis, as this species has been implicated in bacteraemia, osteomyelitis, polyarthritis, peritonitis, urethritis, pyelonephritis, native and prosthetic valve endocarditis as well as infections of permanent pacemarkers, cerebropinal fluid shunts, prosthetic joints and various orthopaedic devices. Staphylococcus haemolyticus may also be associated with human septicaemia, peritonitis, urinary tract infections and native valve endocarditis, while $S$. lugdunensis has been implicated in native and prosthetic valve endocarditis, septicaemia, brain abscess, chronic osteoarthritis, infections of soft tissues, bones and catheters, especially in patients with underlaying diseases. Human infections with $S$. schleiferi subsp. schleiferi are manifested by osteoarthritis, bacteraemia, wound infections, brain empyema as well as infections associated with a jugular catheter and cranial drain. Staphylococcus saprophyticus has been isolated from patients with urinary tract infections (acute cystitis and pyelonephritis), while $S$. simulans has been isolated from those with chronic osteomyelitis. Staphylococcus hominis has been implicated in endocarditis, arthritis, petitonitis and septicaemia, S. capitis in endocarditis, septicaemia and catheter infections. Staphylococcus cohnii has caused urinary tract infections and arthritis, while subspecies of $S$. sciuri have been isolated from wound, skin and soft tissue infections [1].

In production animals, numerous CoNS species (S. chromogenes, S. epidermidis, S. haemolyticus, S. hominis, S. saprophyticus, S. sciuri, S. simulans, S. warneri and S. xylosus) have been associated with clinical and subclinical bovine mastitis 
[56-61], while $S$. sciuri has been reported to cause fatal exudative epidermitis in piglets [62].

The increasing clinical significance of CoNS indicates that safety hazards associated with their occurrence in food can be higher than previously assumed [63]. Numerous species of CoNS have been isolated from cheeses, cured meats, sausages, smoked fishes [64], sea-water fish [65], chlorinated drinking water [52], wild rabbits [66], wild pheasants [67] and from Nigerian traditional fermented foods [68]. In general, the occurrence of virulence factors and antimicrobial resistance is more frequent in clinically important CoNS isolates. As compared with isolates from drinking water, virulence factors are more diversified in clinical CoNS strains. Through genes encoding virulence factors or resistance to antibiotics, CoNS may significantly increase the pathogenic potential of the normal skin microflora, including pathogenic coagulase-positive staphylococci [52].

\subsection{MECHANISMS OF ANTIMICROBIAL RESISTANCE IN STAPHYLOCOCCI}

The results of some studies have demonstrated that antibiotic resistance in staphylococci is an ancient feature, as resistance genes have been found in bacterial strains isolated from permafrost sediments in the River Lena region in Central Yakutia, Russia [69], which may be up to 3.5 million years old [70].

A wide spectrum of beta-lactam antibiotics is traditionally used for the treatment of staphylococcal infections. The occurrence of MRSA strains has led to the use of other drug alternatives, including vancomycin, linezolid and daptomycin [71].

Currently, antibiotic resistance is a key issue affecting public health [7]. Staphylococci may become resistant via the acquisition of antibiotic resistance genes, mediated by transferable genetic elements. Genes encoding antimicrobial resistance can spread horizontally among bacteria, animals and humans [72]. The mechanisms of gene transfer in S. aureus strains include conjugation, transduction and transformation [71].

The primary route of gene acquisition in $S$. aureus strains is bacteriophage transduction. S. aureus strains usually harbour one to four functional bacteriophages, integrated in their genomes as prophages [73,74]. After induction, the prophage enters the lytic cycle, which leads to the lysis of the host cell. During the lytic cycle, bacterial DNA may be packaged into the phage capsid and, upon release from the host cell, further transferred to another recipient cell. This phenomenon is known as "generalised transduction" [75]. 
Plasmids of resistance (R-plasmids) can also be transferred by conjugation. The conjugative transfer of plasmid-encoded resistance genes is recognised as the key mechanism of resistance gene dissemination. The conjugative plasmids carry clusters of genes that encode products necessary for plasmid transfer and mobilisation [70].

The last mechanism of resistance gene transfer is the uptake of both chromosomal and plasmid DNA (including the SCCmecII element) by natural transformation [76]. This process requires a series of naturally encoded competence factors in the $S$. aureus genome. However, there is still no evidence that transformation is a commonly occurring event [70].

A list of antimicrobial resistance genes and mechanisms of resistance in $S$. aureus has been published by Reygaert [21]. Most clinical S. aureus isolates contain mobile genetic elements (plasmids) in the size range of 1-60 kbp, which transfer antimicrobial resistance [70]. The oligonucleotide primers used for PCR determination of resistance genes in staphylococci have been reported by Strommenger et al. [77] and Emaneini et al. [78]. However, bacteria that give positive results in genotypic tests not always show positive phenotypic expression of resistance to relevant antibiotics. Therefore, traditional phenotypic tests are unlikely to be replaced by molecular methods based on the detection of resistance genes [7].

\subsubsection{Resistance to beta-lactams}

Beta-lactams were the first antimicrobial agents introduced into clinical practice and are still used in both human and veterinary medicine. Penicillin was successfully used to treat $S$. aureus infections until 1942, when the penicillin-resistant $S$. aureus strain first appeared. Nowadays, the resistance of staphylococci to antimicrobial agents is an issue of worldwide concern [79].

Resistance to beta-lactams is provided by beta-lactamase (also known as penicillinase), encoded by the blaZ gene [80]. Beta-lactamases deactivate the molecule's antibacterial properties by breaking the antibiotics' structure through hydrolysis of the beta-lactam ring [81]. In general, penicillin-resistant staphylococci are resistant to all penicillinase-labile penicillins, and penicillinsusceptible staphylococci are also susceptible to other beta-lactams used for the treatment of staphylococcal infections [82]. Therefore, new semisynthetic penicillins, resistant to beta-lactamases, have been developed.

Methicillin was introduced in 1960 for the treatment of infections caused by beta-lactamase-producing staphylococci. In 1961, a MRSA has been reported from England and is now a common cause of hospital-acquired infections [83]. Historically, resistance to the penicillinase-stable penicillins has been referred to as "methicillin resistance" or "oxacillin resistance." Strains of S. aureus that express the mecA gene or another mechanism of methicillin resistance (changes in the affinity of penicillin-binding proteins for oxacillin) are known as MRSA. Oxacillin-resistant staphylococci are resistant to all currently 
available beta-lactams, with the exception of the newer cephalosporins with anti-MRSA activity. Therefore, the resistance to a wide range of beta-lactams may be deduced from testing only penicillin and either cefoxitin or oxacillin. Routine testing of other beta-lactam agents that do not show anti-MRSA activity is not advised [82].

Simultaneous resistance to beta-lactam antibiotics (penicillin, methicillin, oxacillin, nafcillin, cloxacillin and dicloxacillin) is known as „intrinsic“ or "methicillin" resistance. This type of resistance has been observed in both coagulase-positive and coagulase-negative staphylococci and is usually accompanied with resistance to other groups of antibiotics, particularly cephalosporins [84]. Methicillin resistance is mediated by the mecA gene, which is carried on a transposon and encodes the synthesis of a novel penicillin-binding protein PBP2a (also called PBP2'), which displays a low affinity for methicillin $[85,86]$. It is composed of three structural domains: a characteristic $\mathrm{N}$-terminal structure, a transpeptidase domain and a nonbinding domain [87].

Exposure of MRSA to methicillin inactivates the four high-affinity-binding PBPs normally present; PBP-2a takes over the functions of these PBPs, thus permitting the cell to grow [88]. However, some $S$. aureus strains harbouring the mecA gene are susceptible to methicillin $[89,90]$. Expression of mecA can be either constitutive or inducible and is modified by the presence of five chromosomal auxiliary genes, $\mathrm{femA}$ to $\mathrm{femE}$ (fem is the factor essential for the expression of methicillin resistance), which affect different steps in the synthesis of peptidoglycan and regulate the degree of resistance without altering the levels of PBP2a [91]. The mecA gene has been cloned and sequenced along with the genes that control its expression, mecR1 encoding the signal transducer protein MecR1 and mecl encoding the repressor protein MecI [92]. Mechanisms of oxacillin resistance other than mecA are rare and include $m e c C$, a novel $m e c A$ homologue [93].

The presence of the mecA gene has been confirmed in S. aureus, S. epidermidis, $S$. haemolyticus, $S$. saprophyticus and S. fleurettii. This gene is carried by the SCCmec staphylococcal cassette chromosome [94]. Various types and subtypes in SCCmec are made up of the mec gene complex and the ccr gene complex, encoding site-specific recombinase(s) for the movement of the element [92].

Based on the degree of homology to the earliest identified mecA gene of $S$. aureus N315 strain, four groups of mecA homologues have been described so far [87]. The first group of mec $A$ gene homologues (mecA1 allotypes) has approximately $80 \%$ nucleotide sequence identity to mecA of N315 and has been identified on the chromosomes of $S$. sciuri subsp. sciuri, S. sciuri subsp. rodentius and $S$. sciuri subsp. carnaticum [95-97]. The second group of mecA gene homologues (mecA2 allotypes) has about $90 \%$ nucleotide identity to mecA of N315 and has been identified in S. vitulinus [98]. The third group of mecA gene homologues (mecB genes) is located on the chromosome and 
plasmids of Macrococcus caseolyticus JCSC5402 and has $62 \%$ nucleotide sequence identity to mecA of N315 [99]. The fourth group of mecA gene homologues (mecC genes), most recently identified in S. aureus strain LGA251, shows $69 \%$ identity to mecA of N315 [100,101].

As most mecA gene homologues are associated with mobile DNA elements, their occurrence cannot be limited to the genus Staphylococcus and is to be expected among other bacterial genera and species [87].

\subsubsection{Resistance to tetracyclines}

Tetracyclines are broad-spectrum bacteriostatic antibiotics widely used in human and veterinary medicine [102]. Therefore, tetracycline resistance is prevalent among bacteria and is encoded by a wide range of determinants [103]. These antimicrobials exhibit activity against numerous Gram-positive and Gram-negative bacteria as well as atypical organisms [104] such as chlamydiae, mycoplasmas, rickettsiae and protozoan parasites [105]. Tetracyclines bind to the bacterial $30 \mathrm{~S}$ ribosomal subunit and inhibit bacterial protein synthesis by preventing the association of aminoacyl-tRNA with the bacterial ribosome [106].

The following two mechanisms of resistance to tetracyclines have been described in staphylococci [107]:

- energy-dependent active efflux of the antibiotic from bacterial cells, resulting from the acquisition of the plasmid-located structural genes tetK [108-110] and tetL [78],

- ribosomal protection by elongation factor-like proteins that are encoded by the transposon located or chromosomal tetM and tetO determinants [111-115].

In $S$. aureus, both active efflux and ribosomal protection have been successfully induced in vitro $[109,111]$. The plasmid pT181, containing 4,437 base pairs (bp), has first been described by Iordanescu in 1976 [116] as the determinant of tetracycline resistance in S. aureus. Sequencing of the tetracycline resistance region of pT181 has shown that it contains a single open reading frame of 1,299 nucleotides [108].

While the tetK gene encodes monoresistance to tetracycline, the tet $M$ gene seems to carry resistance to all drugs of the tetracycline group, including minocycline, a lipophilic analogue of tetracycline. The MRSA isolates typically carry both tetK and tetM genes [117]. Hydropathy plotting indicates that the tetK protein contains 14 transmembrane $\alpha$-helices [110]. The tet $L$ gene is more widespread among streptococci and enterococci [118] and has been confirmed in strains of $S$. aureus that already carry the tetM gene [117]. Although the tetO determinant can be found in other Gram-positive cocci (streptococci and enterococci), no reports about tetO-positive staphylococci are available [107]. 
In recent years, the use of tetracyclines has been limited because of the emergence of microbial resistance, leading to the development of glycylcyclines [104]. Glycylcyclines display activity against strains expressing a variety of different tet genes, including those that encode ribosomal protection and efflux mechanisms [105]. Glycylcyclines are also active against methicillin-resistant staphylococci [104].

\subsubsection{Resistance to macrolides}

In 1952, erythromycin was introduced as the first macrolide antibiotic produced by Saccharopolyspora erythraea. Within a year, the occurrence of erythromycin-resistant strains of staphylococci has been reported from many countries [119].

Macrolide antibiotics stimulate the dissociation of the peptidyl-tRNA molecule from the ribosomes at the time of elongation, resulting in chain termination and a reversible inhibition of protein synthesis. Post-transcriptional modification of the 23S rRNA by adenine-N6 methyltransferase has been described as the first mechanism of macrolide resistance.

Currently, rRNA methylases are the best studied mechanisms of macrolide resistance. Synthesis of adenine-N6 methyltransferases is encoded by the group of erm (erythromycin ribosome methylation) genes. These enzymes methylate a site on the ribosome, and the conformational change results in a decreased ability of macrolides to bind to the ribosome [119-122]. In general, the erm genes have low $\mathrm{G}+\mathrm{C}$ contents (31 to $34 \%$ ) [123], and most of them are associated with conjugative or nonconjugative transposons. These can be found on chromosomes or in plasmids and have a wide host range $[124,125]$. As the modification of the binding site in the $50 \mathrm{~S}$ ribosomal subunit by methylases overlaps the binding site of the other macrolide antibiotics, it is usually manifested as a simultaneous resistance to macrolides, lincosamides and streptogramin $B$ antibiotics $\left(\mathrm{MLS}_{\mathrm{B}}\right)$ [119-122], as well as to the new ketolide drugs [126].

The genes ermA, ermC, encoding erythromycin resistance, and $m s r A$, responsible for the synthesis of ATP-binding protein, are predominant macrolide resistance genes in staphylococci $[119,120,127,128]$. The plasmidencoded gene ermC is most widely distributed in human and animal staphylococci [129].

Two types of expression have been described for the plasmid-encoded ermC gene $[119,130]$. Constitutive expression is associated with three types of mutations in the ermC regulatory region, including deletions [131,132], multiple point mutations [133] and tandem duplications in the ermC translational attenuator [134-136]. Inducible ermC expression requires the presence of a functionally intact regulatory region $5^{\prime}$ for translational attenuation of the ermC methylase gene $[119,137]$. 
Tandem duplications and deletions of different sizes also account for constitutive ermA gene expression in naturally occurring $S$. aureus isolates [138]. Mutations in the ermA gene can arise in vivo as well as in vitro [139]. While the in vitro-derived mutations have been described in human isolates $[140,141)$, in vivo mutation has been documented in a naturally occurring $S$. intermedius isolate of avian origin [126].

The development of constitutive ermC and ermA mutants is a rapid and irreversible process. Constitutive mutants can be obtained in vitro after overnight cultivation in the presence of non-inducers [119,136,139,140]. Therefore, noninducers (lincosamides or streptogramins) are not recommended for the treatment of infections caused by staphylococci which show an inducible macrolide-lincosamide-streptogramin $B$ resistance phenotype [138].

\subsubsection{Resistance to aminoglycosides}

Aminoglycosides are broad-spectrum antibiotics that are used for the treatment of $S$. aureus infections in a combination with other synergistic antibiotics such as beta-lactams or vancomycin. Aminoglycoside antibiotics are not metabolised; they are eliminated by glomerular filtration and excreted as active compounds [142].

Upon contact of Gram-positive bacteria with aminoglycosides, the polycationic molecules of antibiotics are bound to anionic sites of teichoic acid and phospholipids present on their cell surface. The binding causes that the divalent cationic cross-bridges between lipopolysaccharide molecules are displaced, resulting in an increased permeability and the penetration of aminoglycoside molecules into the periplasmic space [143].

Various mechanisms of aminoglycoside resistance have been described; however, most of them have developed in Gram-negative bacteria. In staphylococci, enzymatic inactivation by aminoglycoside-modifying enzymes (AME), such as nucleotidyltransferases, phosphotransferases or acetyltransferases, is the most prevalent mechanism of aminoglycoside resistance [142].

The most common AME-encoding genes among $S$. aureus are aac(6')-Ieaph(2"), aph(3')-IIIa and ant(4')-Ia, which can be harboured on plasmid, chromosome or transposable elements [144]. Resistance to aminoglycosides encoded by the aacA-D gene is more prevalent among the human-based biotypes, because this gene is usually more diffused in staphylococci of human origin [145].

In $S$. aureus, resistance to gentamicin, kanamycin and tobramycin is mediated by a bi-functional enzyme displaying AAC (6') and APH (2") activity [146]. The aac (6')-aph(2") gene is usually present in Tn4001-like transposons [147]. The ANT (4')-IA enzyme inactivates neomycin, kanamycin, tobramycin and 
amikacin, while the APH (3')-III enzyme inactivates neomycin $[148,149]$. Another two enzymes, ANT(9)-Ia and ANT(9)-Ib, have been described to mediate resistance to spectinomycin. The ANT(9)-Ia was first described in $S$. aureus and then also in Enterococcus avium, E. faecalis and E. faecium. The genes coding for these enzymes are known as ant(9)-Ia and ant(9)-Ib, partially making up Tn554 [140,150].

\subsubsection{Resistance to chloramphenicol}

Chloramphenicol, a broad-spectrum antibiotic, has been isolated from Streptomyces venezuelae in 1947 [151] as the first natural substance containing a nitro group [152]. The spectrum of chloramphenicol includes not only Gram-positive and Gram-negative aerobic and anaerobic bacteria, but also chlamydiae, mycoplasmas and rickettsiae [153]. However, because of adverse site effects to meat consumers, arising from chloramphenicol residues in carcasses of slaughter animals (dose-independent irreversible aplastic anaemia), the use of chloramphenicol in human and veterinary medicine has been prohibited by the European Union in 1994 and is currently limited to pets and non-food-producing animals [152,154]. The fluoro substitution at C-3 has led to the synthesis of florfenicol, the fluorinated derivative of chloramphenicol, which does not show any adverse site effects $[153,155,156]$. Both chloramphenicol and florfenicol inhibit bacterial protein synthesis by interacting with the peptidyltransferase centre at the $50 \mathrm{~S}$ of the ribosomal subunit $[152,157]$.

The most common mechanism of chloramphenicol resistance is the enzymatic inactivation of chloramphenicol (as well as thiamphenicol and azidamfenicol) by chloramphenicol acetyltransferases (CATs). Acetylated chloramphenicol can no longer bind to the 50S subunit of the ribosome [152]. Two structural types of CATs can be distinguished: the classical CATs (type A CATs) and the novel CATs, also known as xenobiotic CATs [158].

In staphylococci, acetyltransferases are encoded by three groups of cat genes, A-7, A-8 and A-9, which are located on small multicopy plasmids. The three prototype plasmids include pC194 [159], pC221 [160] and pSCS7 [161]. In addition to chloramphenicol resistance genes, these plasmids can also carry streptomycin resistance [162] or macrolide resistance genes [163]. In some cases, these genes account for a part of multiresistance plasmids [164,165] or conjugative transposons [166]. On the plasmid pSCFS1 from S. sciuri, the $c f r$ gene, conferring resistance to both chloramphenicol and florfenicol, has also been detected [167]. The Cfr methylase modifies A2503 in 23S rRNA and, thereby, mediates resistance to numerous unrelated antibiotics, such as phenicols, lincosamides, pleuromutilins, oxazolidinones and streptogramin A, which bind in close proximity to A2503 at the ribosome [152,167-169]. 


\subsubsection{Resistance to glycopeptides}

The widespread use of vancomycin in the treatment of MRSA infections has led to a decrease in vancomycin susceptibility worldwide. In May 1996, the first occurrence of a MRSA strain with reduced sensitivity to vancomycin (MIC $8 \mathrm{mg} \mathrm{L}^{-1}$ ) has been reported from the Juntendo Hospital in Tokyo (Japan). This strain was isolated from a surgical wound infection that did not respond to vancomycin therapy and became known as "vancomycin-intermediate $S$. aureus" (VISA) [170]. The resistance mechanisms in VISA isolates are less well defined [171]. However, no presence of any imported mobile genetic element has been observed - the increased vancomycin resistance is related to mutations that appear in the invading pathogen during vancomycin therapy in vivo [172].

"Hetero-VISA" (hVISA) strains usually have low vancomycin MIC values (3$8 \mu \mathrm{g} \mathrm{ml}^{-1}$ ), show heterogeneous resistance to beta-lactam antibiotics and serve as precursors of the less frequent homogeneously resistant VISA strains $[170,173,174]$. Mutations described in different VISA isolates cause the transcriptional changes in genes involved in cell wall synthesis [175-181]. The most frequent genetic alterations associated with the VISA phenotype are mutations in the ribosomal gene rpoB [182].

In June 2002, the appearance of the first vancomycin-resistant $S$. aureus (VRSA) strain (MIC $>128 \mu \mathrm{g} \mathrm{ml}^{-1}$ ) has been reported in the United States in a patient who developed a catheter exit-site infection. The VRSA isolate was susceptible to chloramphenicol, tetracycline, minocycline, linezolid, quinupristin/dalfopristin, and trimethoprim/sulfamethoxazole and contained both mecA and vanA genes [183,184]. The strain carried plasmid-borne copies of the transposon Tn1546, which alters the cell wall structure and metabolism and is acquired from vancomycin-resistant Enterococcus faecalis. Conjugative transfer of the vanA gene from vancomycin-resistant enterococci to $S$. aureus has been demonstrated in vivo as well as in vitro. Enterococci have become important reservoir of resistance genes. As there are no barriers for the transfer of these genes among Gram-positive cocci, dissemination of glycopeptide resistance to other pathogenic bacteria, including staphylococci, has occurred [185]. Although the transfer of erythromycin and chloramphenicol resistance has been confirmed among staphylococci, the transmission of vancomycin resistance was not documented [186].

Vancomycin does not interact with enzymes participating in the biosynthesis of the bacterial cell wall, but forms complexes with peptidoglycan precursors. Vancomycin resistance requires the presence of operons that encode enzymes essential for [187]:

- the synthesis of low-affinity precursors (modifying the vancomyinbinding target) or 
- the elimination of the high-affinity precursors produced by the host (removing the vancomycin-binding target).

Target modification (vanA-type resistance) is mediated by transposon Tn1546, which encodes resistance to vancomycin and teicoplanin [187]. This 11-kb transposon is ranked among very stable genetic elements [188]. It encodes nine polypeptides, which can be assigned to various functional groups [185], and is generally carried by transferable plasmids [189] and sometimes by the host chromosome as a part of larger conjugative elements [190]. VanA is the most frequently encountered type of glycopeptide resistance in enterococci. In 2008, vanA-type resistance in $S$. aureus has been reported as rare due to inefficient replication of enterococcal plasmids in staphylococci [185]. In contrary, a very high frequency of vancomycin resistance genes (vanA, vanB) has been reported in $S$. aureus isolates from patients in Shiraz hospitals (south of Iran). The vanA and $v a n B$ resistant genes were detected in 34 and $37 \%$ of clinical isolates, respectively [191].

The VanB gene clusters are generally transferred between chromosomes by conjugation [192]. Regarding the sequence differences, the vanB gene cluster was divided into the three subtypes vanB1, vanB2 and vanB3 [193,194]. Acquired vanB-type resistance results from the synthesis of peptidoglycan precursors ending in the depsipeptide D-ala-D-lac instead of the dipeptide Dala-D-ala [195]. The action of vancomycin is based on the high affinity for the $d$-alanyl-d-alanine (D-ala-D-ala) residue, a component of the bacterial cell wall precursor Lipid II. Alteration of this residue to d-alanyl-d-lactate (D-ala-D-lac) results in a decreased affinity for the antibiotic $[188,190]$.

\subsubsection{Resistance to oxazolidinones}

Oxazolidinones are synthetic drugs with excellent oral bioavailability and a predominantly bacteriostatic effect against Gram-positive bacteria, including methicillin- and vancomycin-resistant staphylococci and enterococci [196-198]. Linezolid was the first oxazolidinone approved for clinical use. The oxazolidinones inhibit bacterial protein synthesis at a very early stage by binding to the 23S rRNA in the 50S ribosomal subunit [198,199].

Linezolid-resistant $S$. aureus has first been isolated in 2001 [200]. Mechanisms of linezolid resistance in staphylococci include point mutations in the $\mathrm{V}$ domain of the 23S rRNA genes, mutations in ribosomal proteins as well as in vivo acquisition of the $c f r$ gene [201] that encodes adenine methyltransferase responsible for modifying the adenosine position in the 23S rRNA [202]. Because of a unique mechanism of action, a lack of cross-resistance between oxazolidinones and other antimicrobials has been reported [203].

\subsubsection{Resistance to lipopeptides}

Lipopeptides represent a diverse group of compounds that consist of a peptide core and a lipid tail and possess a wide therapeutic potential. Daptomycin is a 
new semi-synthetic cyclic lipopeptide antibiotic derived from Streptomyces roseosporus [204] and particularly used in the treatment of infections caused by MRSA or vancomycin-resistant Enterococcus faecium [205]. Currently, the mechanisms of daptomycin action and resistance are not completely understood. However, it is generally accepted that daptomycin penetrates the cytoplasmic membrane of Gram-positive bacteria via a calcium-dependent pathway, which results in bacterial cell wall depolarisation and rapid cell death [206].

Resistance of S. aureus to daptomycin occurs stepwise and slowly. Decreased susceptibility is associated with mutations in $m p r F, y y c G, r p o B$ and $r p o C$ genes [206]. The emergence of daptomycin-resistant $S$. aureus strains is rare and associated with previous vancomycin exposure [207]. The first mechanism of daptomycin resistance in staphylococci is based on the generation of a more positive cell surface charge, preventing the insertion of positively charged daptomycin-calcium by electrostatic repulsion. The second strategy lays in the alteration of the membrane phospholipid composition due to either a decrease in the amount of phosphatidylglycerol available at the membrane interface or changes in membrane fluidity and homeostasis [204].

\subsection{METHICILLIN-RESISTANT STAPHYLOCOCCUS AUREUS (MRSA)}

The MRSA has first been identified in England in 1961 and soon emerged worldwide [208]. Initially, MRSA was mainly a problem in hospital-acquired infections (HA-MRSA). Since the 1990s, MRSA infections have been increasingly reported among populations and are referred to as communityacquired MRSA (CA-MRSA) infection [209,210].

Currently, MRSA has become a serious problem in hospitals as a major nosocomial pathogen responsible for severe morbidity and mortality worldwide. Colonised and infected patients in hospitals and long-term care facilities are the major reservoirs of MRSA, while carriage by the hands of health care workers accounts for the major mechanism for patient-to-patient transmission [211-213]. Thus, hospital-acquired methicillin-resistant $S$. aureus (HA-MRSA) infections spread easily among patients through the hands of the staff and can lead to frequent epidemics [214,215]. Among intensive care unit patients, nasal carriers of $S$. aureus are at higher risk for $S$. aureus bacteraemia than noncarriers. The MRSA colonisation rates in hospitals vary between 10 and $20 \%$ [216,217]. Therefore, hospital sewage is the main source of resistant genes for soil bacteria. As reported by Mandal et al. [218], most S. aureus strains isolated from hospital effluents were resistant to methicillin (MRSA) and tetracycline. Approximately $15 \%$ of MRSA strains showed also VanA-type resistance to vancomycin (VRSA). 
Pneumonia and bacteraemia account for the majority of serious clinical MRSA infections, but intra-abdominal infections, osteomyelitis, toxic shock syndrome, food poisoning and deep tissue infections are also important clinical diseases. Surgical site infections, superficial, deep and organ space, can also be caused by MRSA. Postoperative infection with MRSA is a serious and significant problem in liver transplants, but also in prosthetic devices such as endovascular implants, orthopaedic devices and sternal infections [219].

Recently, studies have reported the occurrence of "invasive" MRSA infections with an overall in-hospital fatality rate of $13 \%$. This type of infection is defined as a positive MRSA culture from a normally sterile site, such as blood, pleural fluid, peritoneal fluid, cerebral spinal fluid or bone. Most frequently, positive blood cultures associated with bacteraemia have been detected [220-222].

The phenotypic expression of methicillin resistance shows great variability, and the two main resistance phenotypes include homogeneous and heterogeneous resistance. In a heterogeneous population, all the bacterial cells harbour genetic markers responsible for methicillin resistance. However, phenotypic expression occurs only in a small fraction of the population, varying from $10^{-2}$ to $10^{-8}$. In a homogeneous single population of bacterial cells, these are inhibited by high levels of antibiotic concentration; homogeneous resistance is the least frequent phenotype [223-225].

The MRSA is generated when methicillin-susceptible S. aureus (MSSA) exogenously acquires a staphylococcal cassette chromosome mec (SCCmec) [226]. It is assumed that under the selective pressure caused by the extensive use of antibiotics, MRSA clones which carry resistance genes can better adapt to environmental changes. The resistant genes include the erm genes (ermA, ermB and erm C) encoding erythromycin resistance, the tet genes (tet $K$, tetL, tet $M$ and tetO) encoding tetracycline resistance and the aac genes [227], namely aph(2), aph(3)-III and ant(4)-I genes, which encode resistance to aminoglycosides $[107,228]$. Adwan et al. have evaluated nine resistance genes in 55 clinical MRSA isolates belonging to SCCmec types II, III, IVa and V. The reported prevalences of ermA, ermC, tetK, tetM, aacA-aphD, vatA, vatB and vatC genes were $30.9,74.5,76.4,16.4,74.5,1.8,0$ and $5.5 \%$, respectively [229].

In general, MRSA strains causing infections in humans can be divided into three epidemiological classes [230]:

- community-associated (CA)-MRSA,

- hospital-associated (HA)-MRSA,

- livestock-associated (LA)-MRSA.

While CA-MRSA and HA-MRSA strains predominantly affect humans, most MRSA isolates in food-producing animals belong to spa-types associated with LA-MRSA. These strains show only limited transmissibility to human populations. However, spa-types associated with CA-MRSA and HA-MRSA have also been reported in food-producing animals [230]. 
The European Food Safety Authority (EFSA) recommends a systematic surveillance of MRSA in humans. Unfortunately, this monitoring is on voluntary base and therefore, only a low number of European countries participated in the monitoring of MRSA in recent years. In 2015, meat from different food-producing animal species showed the presence of MRSA at various levels of prevalence (Table 2).

Table 2. MRSA in food, 2015 [230]

\begin{tabular}{|c|c|c|c|c|c|}
\hline Country & Food category & Description & $\begin{array}{c}\text { Sample } \\
\text { unit }\end{array}$ & $\begin{array}{c}\text { Number } \\
\text { of units } \\
\text { tested }\end{array}$ & $\begin{array}{c}\text { Positive } \\
\text { for MRSA } \\
\text { (\%) }\end{array}$ \\
\hline Finland & Meat from pigs & Fresh, retail, survey & Batch & 303 & $9(3.0 \%)$ \\
\hline \multirow[t]{2}{*}{ Germany } & Meat from pigs & $\begin{array}{c}\text { Carcass, } \\
\text { slaughterhouse, } \\
\text { monitoring - active }\end{array}$ & Batch & 342 & $\begin{array}{c}69 \\
(20.2 \%)\end{array}$ \\
\hline & & $\begin{array}{c}\text { Fresh, retail, } \\
\text { monitoring - active }\end{array}$ & Single & 457 & $\begin{array}{c}60 \\
(13.1 \%) \\
\end{array}$ \\
\hline Switzerland & Meat from pigs & Retail, monitoring & Batch & 301 & $2(0.7 \%)$ \\
\hline Spain & $\begin{array}{l}\text { Meat from } \\
\text { rabbits }\end{array}$ & $\begin{array}{l}\text { Fresh, retail, } \\
\text { surveillance }\end{array}$ & Single & 60 & $5(8.3 \%)$ \\
\hline
\end{tabular}

While Switzerland reported spa-type t034 for positive findings, Finland reported the presence of both spa-type t034 in the meat from cattle as well as spa-type t2741 in pig meat. These spa-types were associated with MRSA clonal complex (CC) 398, the common LA-MRSA in Europe [230].

As seen in Table 3, the presence of MRSA was detected in various age categories of cattle (calves under 1 year of age, dairy cows and meat production animals) in three countries (Belgium, Switzerland and Norway); MRSA-positive pigs were detected in four European countries (Germany, Norway, Spain and Switzerland). 
Table 3. Occurrence of MRSA in healthy food-producing animals, 2015 [230]

\begin{tabular}{|c|c|c|c|c|c|}
\hline Country & Animal & Description & Sample unit & $\begin{array}{c}\text { Number } \\
\text { of units } \\
\text { tested }\end{array}$ & $\begin{array}{c}\text { Positive } \\
\text { for MRSA } \\
\text { (\%) }\end{array}$ \\
\hline \multirow[t]{3}{*}{ Belgium } & $\begin{array}{l}\text { Calves (under } \\
1 \text { year of age) }\end{array}$ & $\begin{array}{c}\text { Farm, monitoring } \\
- \text { active }\end{array}$ & Holding & 147 & $\begin{array}{c}116 \\
(78.9 \%) \\
\end{array}$ \\
\hline & Dairy cows & $\begin{array}{c}\text { Farm, monitoring } \\
- \text { active }\end{array}$ & Holding & 96 & $10(10.4 \%)$ \\
\hline & $\begin{array}{l}\text { Meat } \\
\text { production } \\
\text { animals }\end{array}$ & $\begin{array}{l}\text { Farm, monitoring } \\
- \text { active }\end{array}$ & Holding & 104 & $16(15.4 \%)$ \\
\hline Norway & Cattle & $\begin{array}{c}\text { Farm, control and } \\
\text { eradication } \\
\text { programmes } \\
\end{array}$ & Herd & 179 & $1(0.6 \%)$ \\
\hline Switzerland & $\begin{array}{l}\text { Calves (under } \\
1 \text { year of age) }\end{array}$ & $\begin{array}{c}\text { Slaughterhouse, } \\
\text { monitoring }\end{array}$ & Animal & 292 & $19(6.5 \%)$ \\
\hline \multirow[t]{2}{*}{ Germany } & $\begin{array}{l}\text { Pigs - } \\
\text { breeding } \\
\text { animals } \\
\end{array}$ & $\begin{array}{l}\text { Farm, monitoring } \\
\text { - active }\end{array}$ & Herd & 342 & $90(26.3 \%)$ \\
\hline & $\begin{array}{l}\text { Fattening } \\
\text { pigs }\end{array}$ & $\begin{array}{l}\text { Farm, monitoring } \\
\text { - active }\end{array}$ & Herd & 332 & $\begin{array}{c}137 \\
(41.3 \%)\end{array}$ \\
\hline Norway & Pigs & $\begin{array}{c}\text { Farm, control and } \\
\text { eradication } \\
\text { programmes }\end{array}$ & Herd & 821 & $4(0.5 \%)$ \\
\hline Spain & $\begin{array}{l}\text { Fattening } \\
\text { pigs }\end{array}$ & $\begin{array}{c}\text { Slaughterhouse, } \\
\text { monitoring EFSA } \\
\text { spec. }\end{array}$ & Batch & 383 & $\begin{array}{c}350 \\
(91.4 \%)\end{array}$ \\
\hline Switzerland & $\begin{array}{l}\text { Fattening } \\
\text { pigs }\end{array}$ & $\begin{array}{c}\text { Slaughterhouse, } \\
\text { monitoring }\end{array}$ & Animal & 300 & $77(25.7 \%)$ \\
\hline
\end{tabular}

Several member states have reported data on clinical investigations for MRSA in different kinds of food-producing animals, such as sheep, goats and cattle (Table 4). 
Table 4. Occurrence of MRSA in food-producing animals (clinical investigations, 2015) [230]

\begin{tabular}{lllcc}
\hline Country & Animals & Description & $\begin{array}{c}\text { Number of } \\
\text { animals tested }\end{array}$ & $\begin{array}{c}\text { Positive for } \\
\text { MRSA (\%) }\end{array}$ \\
\hline Ireland & Dairy cows & Farm & 2784 & $1(0.04 \%)$ \\
\hline Netherlands & Dairy cows & Farm & 1344 & $4(0.30 \%)$ \\
\hline Slovakia & Dairy cows & Farm & 366 & $44(12.00 \%)$ \\
\hline & Goats & Farm & 18 & $5(27.80 \%)$ \\
\hline & $\begin{array}{l}\text { Goats (under } \\
\text { 1 year of age) }\end{array}$ & Farm & 3 & $2(66.70 \%)$ \\
\hline Hungary & Milk ewes & Farm & 39 & $14(35.90 \%)$ \\
\hline & $\begin{array}{l}\text { Pheasants, meat } \\
\text { production flocks }\end{array}$ & Farm & 1 & $1(100.00 \%)$ \\
\hline
\end{tabular}

In 2015, the Netherlands and Slovakia have also reported data on MRSA in companion animals, such as cats, dogs or horses (Table 5).

Table 5. MRSA in companion animals (clinical investigations, 2015) [230]

\begin{tabular}{llcc}
\hline Country & Animals & $\begin{array}{c}\text { Number of } \\
\text { animals tested }\end{array}$ & $\begin{array}{c}\text { MRSA-positive } \\
\text { animals (\%) }\end{array}$ \\
\hline \multirow{2}{*}{ Netherlands } & Cats (pet animals) & 53 & $53(100 \%)$ \\
\cline { 2 - 4 } & Dogs (pet animals) & 50 & $50(100 \%)$ \\
\cline { 2 - 4 } & Horses (domestic) & 56 & $56(100 \%)$ \\
\hline \multirow{2}{*}{ Slovakia } & Cats (pet animals) & 108 & $18(16.7 \%)$ \\
\cline { 2 - 4 } & Dogs (pet animals) & 308 & $64(20.8 \%)$ \\
\cline { 2 - 4 } & Horses (domestic) & 1 & $0(0 \%)$ \\
\hline
\end{tabular}

Data on the antimicrobial susceptibility of MRSA isolates from foods and animals have only been reported by three countries (Belgium, Finland and Switzerland). The broth dilution method was used to determine the susceptibility of isolates. All MRSA isolates were resistant to penicillin and cefoxitin; almost all the MRSA isolates were resistant to tetracyclines [230].

Among the MRSA isolates from calves under 1 year of age, tested by Belgium and Switzerland, chloramphenicol resistance was observed in 8.6 and $5.3 \%$ of isolates, respectively. Pig MRSA isolates showed resistance to tiamulin and trimethoprim, probably resulting from the relatively common usage of these drugs in pig medicine in many European countries [230].

Resistance to the important antimicrobials vancomycin and linezolid has not been detected in MRSA from animals or meat in 2015 [230]. 


\subsection{FIGHTING STRATEGIES}

According to data of the World Health Organization (WHO), in the EU, 25,000 patients $(6.25 \%)$ die every year as a result of infections caused by resistant bacteria. Globally the estimated number is as high as 700,000 . If current infection and resistance trends are not reversed, 10 million deaths per year are projected between 2015 and 2050 throughout the world, mostly in Africa and Asia.

Infections caused by multidrug-resistant bacteria in the EU result in extra health care costs and productivity losses of at least $€ 1.5$ billion each year [4].

The Global Action Plan on Antimicrobial Resistance, developed by the WHO, is based on five general strategies [4]:

- to improve the understanding of antimicrobial resistance;

- to strengthen surveillance and research;

- to reduce the incidence of infections;

- to optimise the use of antibiotics;

- to ensure sustainable investment in countering antimicrobial resistance.

To strengthen the standardised global surveillance and research, the WHO supports the collection, analysis and reporting of data on antimicrobial resistance rates at national levels through the Global Antimicrobial Resistance Surveillance System (GLASS), which was developed in 2015 [4].

International standards and guidelines, aimed at the testing of antimicrobial resistance, are prepared by the Clinical and Laboratory Standards Institute (CLSI). The CLSI Subcommittee on Antimicrobial Susceptibility Testing develops new or revised reference methods for antimicrobial susceptibility tests and establishes breakpoints for the results of such tests as well as quality control parameters. This way, the Subcommittee provides useful information for clinicians and supports them in treating patients with the most effective antimicrobials to decrease antimicrobial resistance [82].

In general, microorganisms are categorised, according to minimal inhibitory concentrations (MICs) or zone diameter values, into the following classes: susceptible, susceptible-dose dependent, intermediate, non-susceptible and resistant. Resistant bacteria are defined as those that are not inhibited by the usually achievable concentrations of the agent with normal dosage schedules and, therefore, clinical efficacy of the agent against the isolate has not been reliably shown in treatment studies [82].

Interpretative categories, including breakpoints of selected antibiotics for Staphylococcus spp. using the Disk diffusion test [231] and the Broth or Agar dilution tests [232] in accordance with CLSI performance standards for antimicrobial susceptibility testing, are presented in Table 6 [82]. 
Table 6. Selected MIC and zone diameter breakpoints for Staphylococcus spp. [82]

\begin{tabular}{|c|c|c|c|c|c|c|c|}
\hline & \multirow{3}{*}{$\begin{array}{c}\text { Disk } \\
\text { Content }\end{array}$} & \multicolumn{3}{|c|}{$\begin{array}{l}\text { MIC Breakpoints } \\
\left(\mu \mathrm{g} \mathrm{ml}^{-1}\right)\end{array}$} & \multicolumn{3}{|c|}{$\begin{array}{c}\text { Zone Diameter } \\
\text { Breakpoints }(\mathrm{mm})\end{array}$} \\
\hline & & $\mathrm{S}$ & $\mathrm{I}$ & $\mathrm{R}$ & $\mathrm{S}$ & I & $\mathrm{R}$ \\
\hline & & $\leq$ & $=$ & $\geq$ & $\geq$ & $=$ & $\leq$ \\
\hline Penicillin & 10 units & 0.12 & & 0.25 & 29 & & 28 \\
\hline \multirow[t]{2}{*}{$\begin{array}{l}\text { Oxacillin } \\
\text { for } S . \text { aureus and } S . \text { lugdunensis }\end{array}$} & & 2 & - & 4 & - & - & - \\
\hline & $\begin{array}{l}30 \mu \mathrm{g} \\
\text { cefoxitin }\end{array}$ & 4 & - & 8 & 22 & - & 21 \\
\hline \multirow{2}{*}{$\begin{array}{l}\text { for CoNS except } S \text {. lugdunensis } \\
\text { and } S \text {. pseudintermedius }\end{array}$} & & 0.25 & - & 0.5 & - & - & - \\
\hline & $\begin{array}{l}30 \mu \mathrm{g} \\
\text { cefoxitin }\end{array}$ & - & - & - & 25 & - & 24 \\
\hline for S. pseudintermedius & $1 \mu \mathrm{g}$ & 0.25 & - & 0.5 & 18 & - & 17 \\
\hline Ceftaroline & $30 \mu \mathrm{g}$ & 1 & 2 & 4 & 24 & $21-23$ & 20 \\
\hline $\begin{array}{l}\text { Vancomycine } \\
\text { for S. aureus }\end{array}$ & & 2 & $4-8$ & 16 & - & - & - \\
\hline for CoNS & & 4 & 8-16 & 32 & - & - & - \\
\hline Daptomycin & & 1 & - & - & - & - & - \\
\hline Gentamicin & $10 \mu \mathrm{g}$ & 4 & 8 & 16 & 15 & $13-14$ & 12 \\
\hline Amikacin & $30 \mu \mathrm{g}$ & 16 & 32 & 64 & 17 & $15-16$ & 14 \\
\hline Kanamycin & $30 \mu \mathrm{g}$ & 16 & 32 & 64 & 18 & $14-17$ & 13 \\
\hline Tobramycin & $10 \mu \mathrm{g}$ & 4 & 8 & 16 & 15 & $13-14$ & 12 \\
\hline Azithromycin & $15 \mu \mathrm{g}$ & 2 & 4 & 8 & 18 & $14-17$ & 13 \\
\hline Erythromycin & $15 \mu \mathrm{g}$ & 0.5 & $1-4$ & 8 & 23 & $14-22$ & 13 \\
\hline Tetracycline and Minocycline & $30 \mu \mathrm{g}$ & 4 & 8 & 16 & 19 & $15-18$ & 14 \\
\hline Ciprofloxacin & $5 \mu \mathrm{g}$ & 1 & 2 & 4 & 21 & $16-20$ & 15 \\
\hline Ofloxacin & $5 \mu \mathrm{g}$ & 1 & 2 & 4 & 18 & $15-17$ & 14 \\
\hline Clindamycin & $2 \mu \mathrm{g}$ & 0.5 & $1-2$ & 4 & 21 & $15-20$ & 14 \\
\hline Chloramphenicol & $30 \mu \mathrm{g}$ & 8 & 16 & 32 & 18 & $13-17$ & 12 \\
\hline Rifampin & $5 \mu \mathrm{g}$ & 1 & 2 & 4 & 20 & $17-19$ & 16 \\
\hline Quinupristin-dalfopristin & $15 \mu \mathrm{g}$ & 1 & 2 & 4 & 19 & $16-18$ & 15 \\
\hline Linezolid & $30 \mu \mathrm{g}$ & 4 & - & 8 & 21 & - & 20 \\
\hline Sulfonamides & $\begin{array}{l}250 \text { or } \\
300 \mu \mathrm{g}\end{array}$ & 256 & - & 512 & 17 & $13-16$ & 12 \\
\hline Trimetoprim & $5 \mu \mathrm{g}$ & 8 & - & 16 & 16 & $11-15$ & 10 \\
\hline
\end{tabular}


As demonstrated in Table 6, cefoxitin can be used to predict the presence of mecA-mediated oxacillin resistance in $S$. aureus and S. lugdunensis. While the disk diffusion test is preferred for coagulase-negative staphylococci (except $S$. lugdunensis), dilution tests are the preferred methods for coagulase-positive staphylococci and $S$. lugdunensis. Oxacillin is the preferred agent if a penicillinase-stable penicillin is tested. The results of such testing can be applied to other penicillinase-stable penicillins. For staphylococci that test susceptible, aminoglycosides are used only in combination with other active agents that test susceptible [82].

Prevention and control of antimicrobial resistance through optimising the use of antibiotics require changes in human behaviour. People should only use antibiotics when they are prescribed by a health professional, follow advices of a health worker and avoid any use of leftover drugs. The problem of antimicrobial resistance is becoming more significant in countries where antibiotics can be bought without prescription [233]. However, it is better to prevent staphylococcal infections, e.g. by avoiding close contact with sick people, by washing hands, by covering the nose and mouth when sneezing and via good manufacturing practices in the food industry.

Staphylococci can easily be spread by infected persons, animals or foods of animal origin. The spread is encouraged by inadequate sanitary conditions, inappropriate hand washing techniques or food-handling procedures. Personto-person transmission is facilitated by close contact. It has been reported that (HA)-MRSA colonisation rates could significantly be reduced (by 66\%) by using alcohol-based hand rub as the most effective method of hand hygiene [215]. Staphylococci can be spread through touch between patients and hospital personnel as well as between people and food-producing or companion animals.

To prevent and control the spread of resistance among staphylococci in the agriculture sector, it is necessary to improve biosecurity on farms, to prevent infections through improved hygiene and animal welfare, to use antibiotics only under veterinary supervision, to apply good practices at each step of producing and processing foods from animal sources and to abstain from the use of antibiotics to prevent diseases in healthy animals [233].

In food-producing animals and agricultural workers, staphylococci are present on the skin surface and can be spread between animals and humans through direct contact. Heat processing of food (pasteurization) results in the elimination of most viable bacterial cells, but is not able to destroy persistent genetic material (DNA). When ingested, genes encoding antimicrobial resistance are released to the digestive tract of the consumer and may be acquired by other susceptible bacteria. Thus, fighting strategies in both the primary production and the food-processing industry consist of the prevention 
of staphylococci in raw materials and finished food products rather than in the reduction of their numbers by further heat processing.

Resistance genes can also be disseminated by potable water and wastewaters. In particular, effluences from hospitals may significantly contribute to spreading resistance in the environment. Therefore, sewage treatment should not only devitalize the emerged bacteria, but rather, a complete destruction of DNA is necessary to inactivate genes encoding virulence factors and antimicrobial resistance. As recently reported, DNA degradation begins at $130{ }^{\circ} \mathrm{C}$ and continues in a linear manner until complete degradation at around $190^{\circ} \mathrm{C}$. The combination of moist heat and pressure makes the DNA more sensitive and enables degradation at around $90^{\circ} \mathrm{C}$ [234].

The occurrence of staphylococci has been observed in samples of drinking water, wastewaters [235] and biofilms from hospital wastewater [236]. The presence of the mecA gene has been reported in $S$. epidermidis, present in chlorinated drinking water [52], as well as in a biofilm from hospital wastewaters [236]. Municipal and swine slaughterhouse wastewaters may also participate in the dissemination of the $m e c A$ gene and MRSA and pose a health risk not only to workers, but also to the general public [237]. Soil contaminated with wastewater represents a reservoir of resistant genes. Therefore, both water and soil significantly contribute to a rapid increase in antimicrobial resistance throughout the world.

\subsection{CONCLUSION}

Resistance of staphylococci to antibiotics is a problem of global public health and food security. When exposed to antimicrobials, staphylococci develop various resistance mechanisms that can emerge and spread worldwide. Currently, the phenomenon of antimicrobial resistance can affect any country of the world. Infections caused by multidrug-resistant $S$. aureus (MRSA) and $S$. epidermidis (MRSE) strains result in prolonged hospital stays, higher medical costs and increased mortality. Therefore, tackling antimicrobial resistance is a high priority of the World Health Organization. As the resistance is mainly caused by the misuse or overuse of antibiotics, international cooperation across all government sectors (in particular the human health sector, the animal health sector and the agricultural sector) is required. Effective measures must be taken at each level to stop the spread of resistance. To understand the genetic mechanisms of antimicrobial resistance, further studies are required to monitor resistance genes in isolates of staphylococci from food-producing and companion animals, humans, finished food products as well as from the environment. 


\section{REFERENCES}

1. K.H. Schleifer, J.A. Bell, in Bergey's Manual of Systematic Bacteriology, $2^{\text {nd }}$ ed., vol. 3, P. Vos, G. Garrity, D. Jones, N.R. Krieg, W. Ludwig, F.A. Rainey, K.H.

Schleifer, W.B. Whitman, Eds., Springer-Verlag, New York, USA, 2009, p. 392421.

2. L.H. Lambert, T. Cox, K. Mitchell, R.A. Rosselló-Mora, C. Del Cueto, D.E. Dodge, P. Orkand, R.J. Cano, Int. J. Syst. Bacteriol. 48 (1998) 511-518.

3. J.E. Rubin, K.R. Ball, M. Chirino-Trejo, Can. Vet. J. 52 (2011) 153-157.

4. World Health Organization Antimicrobial resistance http://www.euro.who.int/en/health-topics/diseaseprevention/antimicrobial-resistance (Feb 25, 2018).

5. C. Faria, I. Vaz-Moreira, E. Serapicos, O.C. Nunes, C.M. Manaia, Sci. Total Environ. 407 (2009) 3876-3882.

6. M.T. Wan, C.C. Chou, Water Res. 64 (2014) 288-295.

7. N. Woodford, A. Sundsfjord, J. Antimicrob. Chemother. 56 (2005) 259-261.

8. W.E. Kloos, K.H. Schleifer, F. Götz, in The Prokaryotes. A Handbook on the Biology of Bacteria. Ecophysiology, Isolation, Identification, Applications, vol. II, $2^{\text {nd }}$ ed., A. Balows, H.G. Trüper, M. Dworkin, W. Harder, K.H. Schleifer, Eds., Springer, New York, USA, 1992, 1369-1420.

9. S. Hess, C. Gallert, Int. J. Syst. Evol. Microbiol. 65 (2015) 2661-2665.

10. S.Y.C. Tong, F. Schaumburg, M.J. Ellington, J. Corander, B. Pichon, F. Leendertz, S.D. Bentley, J. Parkhill, D.C. Holt, G. Peters, P.M. Giffard, Int. J. Syst. Evol. Microbiol. 65 (2015) 15-22.

11. M. Mednář, V. Fraňková, J. Schindler, A. Souček, J. Vávra, Lékařská mikrobiologie, Marvil, Praha, Czech republic, 1996, pp. 558.

12. W.E. Kloos, D.W. Lamb Jr., in Manual of Clinical Microbiology, $5^{\text {th }}$ ed., A. Balows, Ed., American Society for Microbiology, Washington, USA, 1991, p. 222.

13. M.C. Maranan, B. Moreira, S. Boyle-Vavra, R.S. Daum, Infect. Dis. Clin. North Am. 11 (1997) 813-849.

14. $\quad$ S.H. Goh, S.K. Byrne, J.L. Zhang, A.W. Chow, J. Clin. Microbiol. 30 (1992) 16421645.

15. P. Phonimdaeng, M. O’Reilly, P. Nowlan, A.J. Bramley, T.J. Foster, Mol. Microbiol. 4 (1990) 393-404.

16. D.A. Hamza, S.M. Dorgham, A. Arafa, Adv. Infect. Dis. 5 (2015) 196-203.

17. G. Sakoulas, H.S. Cold, L. Vencataraman, P.C. Degirolami, G.M. Eliopouls, Q. Qian, J. Clin. Microbiol. 39 (2001) 3946-3951.

18. D. Osmonov, K.S. Ozcan, I. Erdinler, S. Altay, E. Yildirim, C. Turkkan, A. Ekmekci, B. Gungor, K. Gurkan, J. Cardiol. 61 (2013) 175-180.

19. S.N. Sajadi, H. Kaboosi, F.P. Ghadikolii, Zahedan J. Res. Med. Sci. 19 (2017) e55079.

20. R. Talebi-Satlou, M. Ahmadi, H.D. Saei, Jundishapur J. Microbiol. 5 (2012) 416420.

21. F.A. Waldvogel, in Principles and practice of infectious diseases, vol. 1, G.L. Mandell, J.E. Bennett, R. Dolin, Eds., Churchill Livingstone Elsevier, New York, USA, 1995, p. 2069. 
22. W.C. Reygaert, in Microbial pathogens and strategies for combating them: science, technology and education, vol. 1, ed. 1, A. Nendez-Vilas (Ed.), Formatex Research Center, Badajoz, Spain, 2013, p. 297-305.

23. M.D. Kasper, in Harrison's Manual of Medicine, $17^{\text {th }}$ ed., A.S. Fauci, E. Braunwald, D.L. Kasper, S.L. Hauser, D.L. Longo, J.L. Jameson, J. Loscalzo, Eds., McGraw-Hill Medical, New York, USA, 2009, 489-496.

24. D.G. Conway, R.F. Lyon, J.D. Heiner, Ann. Emerg. Med. 61 (2013) 118,129.

25. S. Ladhani, FEMS Immunol. Med. Microbiol. 39 (2003) 181-189.

26. Y. Hanakawa, J.R. Stanley, J. Biochem. 136 (2004) 747-750.

27. P. Sah, K.R. Rijal, B. Shakya, B.R. Tiwari, P. Ghimire, J. Health Appl. Sci. 3 (2013) 21-23.

28. J. Todd, M. Fishaut, F. Kapral, T. Welch, Lancet 312 (1978) 1116-1118.

29. K.N. Shands, G.P. Schmid, B.B. Dan, D. Blum, R.J. Guidotti, N.T. Hargrett, R.L. Anderson, D.L. Hill, C.V. Broome, J.D. Band, D.W. Fraser, N. Engl. J. Med. 303 (1980) 1436-1442.

30. M.A. Argudín, M.C. Mendoza, M.R. Rodicio, Toxins 2 (2010) 1751-1773.

31. I.V. Pinchuk, E.J. Beswick, V.E. Reyes, Toxins 2 (2010) 2177-2197.

32. Y. Loir, F. Baron, M. Gautier, Genet. Mol. Res. 2 (2003) 63-76.

33. Commission Regulation (EC) No. 2073/2005 of 15 November 2005 on microbiological criteria for foodstuffs, OJEU L 338 (2005) 1-26.

34. B. Janštová Jr., L. Necidová, A. Skočková, B. Janštová, J. Food Nutr. Res. 53 (2014) 389-392.

35. R. De La Fuente, G. Suarez, K.H. Schleifer, Int. J. Syst. Bacteriol. 35 (1985) 99102.

36. N. Wang, A.M. Neilan, M. Klompas, Infect. Dis. Rep. 5 (2013) 6-11.

37. M. Foissac, M. Lekaditi, B. Loutfi, A. Ehrhart, F.A. Dauchy, Germs 6 (2016) 106110.

38. M.G. Frank, A. Keniston, N. Madinger, C. Price, M.T. Bessesen, JMM Case Reports (2015), doi 10.1099/jmmcr.0.000066.

39. D.A. Talan, D. Staatz, A. Staatz, E.J. Goldstein, K. Singer, G.D. Overturf, J. Clin. Microbiol. 27 (1989) 78-81.

40. T. Kelesidis, S. Tsiodras, Int. J. Infect. Dis. 14 (2010) 838-841.

41. I. Zdovc, M. Ocepek, T. Pirš, B. Krt, L. Pinter, J. Vet. Med. Series B 51 (2004) 449454.

42. P.E. Varaldo, R. Kilpper-Balz, F. Biavasco, G. Satta, K.H. Schleifer, Int. J. Syst. Bact. 38 (1988) 436-439.

43. J.R. Roberson, L.K. Fox, D.D. Hancock, J.M. Gay, T.E. Besser, Am. J. Vet. Res. 57 (1996) 54-58.

44. L.A. Devriese, K. Vlaminck, J. Nuytten, P. De Keersmaecker, Equine Vet. J. 15 (1983) 263-265.

45. Y. Ueda, Y. Aohagi, J. Japan. Vet. Med. Assoc. 60 (2007) 663-665.

46. W.E. Phillips Jr., R.E. King, W.E. Kloos, Am. J. Vet. Res. 41 (1980) 274-276.

47. C. L'Ecuyer, K. Jericho, Can. J. Comp. Med. Vet. Sci. 30 (1966) 94-101.

48. G.E. Onet, J.L. Pommer, J. Am. Vet. Med. Assoc. 199 (1991) 362-363.

49. M. Otto, Front. Biosci. 9 (2004) 841-863.

50. M.L.R.S. Cunha, L.M.S.S. Rugolo, C.A.M. Lopes, Mem. Inst. Oswaldo Cruz 101 (2006) 661-668.

51. M.L.R.S. Cunha, R.A.O. Calsolari, Microbiol. Insight. 1 (2008) 1-13. 
52. Z. Čuvalová, M. Pipová, M. Kantíková, A. Brtková, J. Fajber, Open Life Sci. 10 (2015) 328-338.

53. O. Olsvik, K. Fossum, B.P Berdal, Acta Pathol. Microbiol. Immunol. Scand. B 90 (1982) 441-444.

54. N. Balaban, A. Rasooly, Int. J. Food Microbiol. 61 (2000) 1-10.

55. A. Longauerová, Bratisl. Lek. Listy 107 (2006) 448-452.

56. B.M. Thorberg, M.L. Danielsson-Tham, U. Emanuelson, K. Persson Waller, J. Dairy Sci. 92 (2009) 4962-4970.

57. A.T. Fessler, C. Billerbeck, K. Kadlec, S. Schwarz, J. Antimicrob. Chemother. 65 (2010) 1576-1582.

58. J.Y. Park, L.K. Fox, K.S. Seo, M.A. McGuire, Y.H. Park, F.R. Rurangirwa, W.M. Sischo, G.A. Bohach, Vet. Microbiol. 147 (2011) 149-154.

59. M. Bochniarz, W. Wawron, M. Szczubiał, Pol. J. Vet. Sci. 16 (2013) 487-492.

60. A. Ruaro, C. Andrighetto, S. Torriani, A. Lombardi, Food Microbiol. 34 (2013) 106-111.

61. S. Hosseinzadeh, H.D. Saei, Int. J. Vet. Sci. Med. 2 (2014) 27-34.

62. S. Chen, Y. Wang, F. Chen, H. Yang, M. Gan, S.J. Zheng, PLoS ONE 2 (2007) e147.

63. S. Even, S. Leroy, C. Charlier, N.B. Zakour, J.P. Chacornac, I. Lebert, E. Jamet, M.H. Desmonts, E. Coton, S. Pochet, P.Y. Donnio, M. Gautier, R. Talon, Y. Le Loir, Int. J. Food Microbiol. 139 (2010) 87-95.

64. W. Chajęcka-Wierzchowska, A. Zadernowska, B. Nalepa, M. Sierpińska, Ł. Łaniewska-Trokenheim, Food Microbiol. 46 (2015) 222-226.

65. I. Regecová, M. Pipová, P. Jevinová, K. Marušková, V. Kmet’, P. Popelka, J. Food Sci. 79 (2014) M898-M902.

66. M. Pipová, P. Jevinová, V. Kmet', I. Regecová, K. Marušková, Eur. J. Wildlife Res. 58 (2012) 157-165.

67. I. Regecová, M. Pipová, P. Jevinová, V. Kmet', J. Výrostková, D. Sopková, Italian J. Anim. Sci. 13 (2014) 627-630.

68. P.T. Fowoyo, S.T. Ogunbanwo, Can. J. Microbiol. 62 (2016) 572-578.

69. E. Kashuba, A.A. Dmitriev, S.M. Kamal, O. Melefors, G. Griva, U. Römling, I. Ernberg, V. Kashuba, A. Brouchkov, Microb. Ecol. Health Dis. 28 (2017), https://doi.org/10.1080/16512235.2017.1345574, (Feb 17, 2018).

70. D.C. Zhang, A. Brouchkov, G. Griva, F. Schinner, R. Margesin, Biology (Basel) 2 (2013) 85-106.

71. J. Haaber, J. R. Penadés, H. Ingmer, Trends Microbiol. 25 (2017) 893-905.

72. M. Teuber, Cell. Mol. Life. Sci. 56 (1999) 755-763.

73. J.A. Lindsay. Int. J. Med. Microbiol, 304 (2014) 103-109.

74. C. Goerke, R. Pantucek, S. Holtfreter, B. Schulte, M. Zink, D. Grumann, B.M. Bröker, J. Doskar, C. Wolz, J. Bacteriol. 191 (2009) 3462-3468.

75. N.D. Zinder, J. Cell. Physiol. 45 (1955) 23-49.

76. K. Morikawa, A.J. Takemura, Y. Inose, M. Tsai, Le T.N. Thi, T. Ohta, T. Msadek, PLoS Pathog. 8 (2012) e1003003.

77. B. Strommenger, C. Kettlitz, G. Werner, W. Witte, J. Clin. Microbiol. 41 (2003) 4089-4094.

78. M. Emaneini, R. Bigverdi, D. Kalantar, S. Soroush, F. Jabalameli, B. Noorazar Khoshgnab, P. Asadollahi, M. Taherikalani, Ann. Burns Fire Disasters 26 (2013) 76-80.

79. M.P. Jevons, Br. Med. J. 1 (1961) 124-125.

80. N. Malachowa, F.R. DeLeo, Cell. Mol. Life Sci. 67 (2010) 3057-3071. 
81. E.P. Abraham, E. Chain, Nature 46 (1940) 837-837.

82. CLSI (Clinical and Laboratory Standards Institute). Performance standards for antimicrobial susceptibility testing $-27^{\text {th }}$ ed. CLSI Supplement M 100, 2017, $250 \mathrm{pp}$.

83. S. Deresinski, Clin. Infect. Dis. 40 (2005) 562-573.

84. M.C. Maranan, B. Moreira, S. Boyle-Vavra, R.S. Daum, Infect. Dis. Clin. North Am. 11 (1997) 813-849.

85. H.C. Neu, Science 257 (1992) 1064-1073.

86. B.G. Spratt, Science 264 (1994) 388-393.

87. T. Ito, K. Hiramatsu, A. Tomasz, H. de Lencastre, V. Perreten, M.T.G. Holden, D.C. Coleman, R. Goering, P.M. Giffard, R.L. Skovi, K. Zhang, H. Westh, F. O’Brien, F.C. Tenover, D.C. Oliveira, S. Boyle-Vavra, F. Laurent, A.M. Kearns, B. Kreiswirth, K. Soo Ko, H. Grundmann, J.E. Sollid, J.F. John Jr., R. Daum, B. Soderquist, G. Buistx, Antimicrob. Agents Chemother. 56 (2012) 4997-4999.

88. H.F. Chambers, Postgrad. Med. 109 (2001) 43-50.

89. K. Hiramatsu, Microbiol. Immunol. 39 (1995) 531-543.

90. D.M. Niemeyer, M.J. Pucci, J.A. Thanassi, V.K. Sharma, G.L. Archer, J. Bacteriol. 178 (1996) 5464-5471.

91. K. Murakami, A. Tomasz, J. Bacteriol. 171 (1989) 874-879.

92. International Working Group on the Classification of Staphylococcal Cassette Chromosome Elements (IWG-SCC) , Antimicrob. Agents Chemother. 53 (2009) 4961-4967.

93. A. Medhus, J.S. Slettemea, L. Marstein, K.W. Larssen, M. Sunde, J. Antimicrob. Chemother. 68 (2013) 968-975.

94. S. Tsubakishita, K. Kuwahara-Arai, T. Sasaki, K. Hiramatsu, Antimicrob. Agents Chemother. 54 (2010) 4352-4359.

95. S. Wu, C. Piscitelli, H. de Lencastre, A. Tomasz, Microb. Drug Resist. 2 (1996) 435-441.

96. S. Wu, H. de Lencastre, A. Tomasz, J. Bacteriol. 180 (1998) 236-242.

97. I. Couto, H. de Lencastre, E. Severina, W. Kloos, J.A. Webster, R.J. Hubner, I.S. Sanches, A. Tomasz, Microb. Drug Resist. 2 (1996) 377-391.

98. C. Schnellmann, V. Gerber, A. Rossano, V. Jaquier, Y. Panchaud, M. G. Doherr, A. Thomann, R. Straub, V. Perreten, J. Clin. Microbiol. 44 (2006) 4444-4454.

99. T. Baba, K. Kuwahara-Arai, I. Uchiyama, F. Takeuchi, T. Ito, K. Hiramatsu, J. Bacteriol. 191 (2009) 1180-1190.

100. L. Garcia-Alvarez, M.T.G. Holden, H. Lindsay, C.R. Webb, D.F.J. Brown, M.D. Curran, E. Walpole, K. Brooks, D.J. Pickard, C. Teale, J. Parkhill, S.D. Bentley, G.F. Edwards, E.K. Girvan, A.M. Kearns, B. Pichon, R.L.R. Hill, A.R. Larsen, R.L. Skov, S.J. Peacock, D.J. Maskell, M.A. Holmes, Lancet Infect. Dis. 11 (2011) 595-603.

101. A.C. Shore, E.C. Deasy, P. Slickers, G. Brennan, B. O'Connell, S. Monecke, R. Ehricht, D.C. Coleman, Antimicrob. Agents Chemother. 55 (2011) 3765-3773.

102. S.B. Levy, The antibiotic paradox: how miracle drugs are destroying the miracle, Plenum Press, New York, USA, 1992, pp. 279.

103. M.C. Roberts, FEMS Microbiol. Rev. 19 (1996) 1-24.

104. G.G. Zhanel, K. Homenuik, K. Nichol, A. Norredin, L. Vercaigne, J. Embil, A. Gim, J.A. Karlowsky, D.J. Hoban, Drugs 64 (2004) 63-88.

105. I. Chopra, M. Roberts, Microbiol. Mol. Biol. Rev. 65 (2001) 232-260.

106. D. Schnappinger, W. Hillen, Arch. Microbiol. 165 (1996) 359-369. 
107. K. Trzcinski, B.S. Cooper, W. Hryniewicz, C.G. Dowson, J. Antimicrob. Chemother. 45 (2000) 763-770.

108. S.A. Khan, R.P. Novick, Plasmid 10 (1983) 251-259.

109. M. Mojumdar, S.A. Khan, J. Bacteriol. 170 (1988) 5522-5528.

110. G.G. Guay, S.A. Khan, D.M. Rothstein, Plasmid 30 (1993) 163-166.

111. M. Nesin, P. Svec, J.R. Lupski, G.N. Godson, B. Kreiwirth, J. Kornblum, S.J. Projan, Antimicrob. Agents Chemother. 34 (1990) 2273-2276.

112. S. Schwarz, M.C. Roberts, C. Werckenthin, Y.J. Pang, C. Lande, Vet. Microbiol. 63 (1998) 217-227.

113. S. Esposito, S. Leone, E. Petta, S. Noviello, F. Iannjello, Int. J. Antimicrob. Agents 34 (2009) 30-35.

114. N. McCallum, B. Berger-Bächi, M.M. Senn, Int. J. Med. Microbiol. 300 (2010) 118-129.

115. E. Michalová, P. Novotná, J. Schlegelová, Vet. Med. (Czech). 49 (2004) 79-100.

116. S. Iordanescu, Arch. Roum. Pathol. Exp. Microbiol. 35 (1976) 111-118.

117. R. Bismuth, R. Zilhao, H. Sakamoto, J.L. Guesdon, P. Courvalin, Antimicrob. Agents Chemother. 34 (1990) 1611-1614.

118. R. Zilhao, B. Papadopoulou, P. Courvalin, Antimicrob. Agents Chemother. 32 (1988) 1793-1796.

119. B. Weisblum, Antimicrob. Agents Chemother. 39 (1995) 797-805.

120. R. Leclercq, P. Courvalin. Antimicrob. Agents Chemother. 35 (1991) 1267-1272.

121. B. Weisblum, Antimicrob. Agents Chemother. 39 (1995) 577-585.

122. B. Weisblum, Drug Resist. Updat. 1 (1998) 29-41.

123. M.C. Roberts, J. Sutcliffe, P. Courvalin, L.B. Jensen, J. Rood, H. Seppala, Antimicrob. Agents Chemother. 43 (1999) 2823-2830.

124. P. Trieu-Cuot, C. Poyart-Salmeron, C. Carlier, P. Courvalin, Nucleic Acids Res. 18 (1990) 3660.

125. A.A. Salyers, N.B. Shoemaker, A.M. Stevens, L.Y. Li, Microbiol. Rev. 59 (1995) 579-590.

126. C. Werckenthin, S. Schwarz, J. Antimicrob. Chemother. 46 (2000) 785-788.

127. P. Luthje, S. Schwarz, J. Antimicrob. Chemother. 57 (2006) 966-969.

128. F.A. Bagcigil, A. Moodley, K.E. Baptiste, V.F. Jensen, L. Guardabassi, Vet. Microbiol. 121 (2007) 307-315.

129. B.R. Lyon, R. Skurray, Microbiol. Rev. 51 (1987) 88-134.

130. N.E. Allen, Antimicrob. Agents Chemother. 11 (1977) 669-674.

131. I. Catchpole, C. Thomas, A. Davies, K.G.H. Dyke, J. Gen. Microbiol. 134 (1988) 697-709.

132. I. Catchpole, K.G.H. Dyke, FEMS Microbiol. Lett. 69 (1990) 43-48.

133. S. Schwarz, C. Lange, C. Werckenthin, J. Med. Microbiol. 47 (1998) 63-70.

134. G. Lodder, S. Schwarz, P. Gregory, K. Dyke, Antimicrob. Agents Chemother, 40 (1996) 215-217.

135. S.S. Oliveira, E. Murphy, M.R. Gamon, M.C.F. Bastos, J. Gen. Microbiol. 139 (199) 1461-1467.

136. C. Werckenthin, S. Schwarz, H. Westh, Antimicrob. Agents Chemother. 43 (1999) 1681-1685.

137. B. Weisblum, J. Antimicrob. Chemother. 16 (1985) 63-90.

138. F.J. Schmitz, J. Petridou, N. Astfalk, S. Scheuring, K. Köhrer, J. Verhoef, A.C. Fluit, S. Schwarz, Antimicrob. Agents Chemother. 45 (2001) 1603-1604.

139. B.C. Lampson, J.T. Parisi, J. Bacteriol. 166 (1986) 479-483. 
140. E. Murphy, J. Bacteriol. 162 (1985) 633-640.

141. P. Sandler, B. Weisblum, J. Mol. Biol. 203 (1988) 905-915.

142. M.S. Ramirez, M.E. Tolmasky, Drug Resist. Updates 13 (2010) 151-171.

143. R. Vanhoof, P. Sonck, E. Hannecart-Pokorni, J. Antimicrob. Chemother. 35 (1995) 167-171.

144. M. Emaneini, M. Taherikalani, M.A. Eslampour, H. Sedaghat, M. Aligholi, F. Jabalameli, S. Shahsavan, N. Sotoudeh, Microb. Drug Resist. 15 (2009) 129-132.

145. S. Johler, F. Layer, R. Stephan, J. Food Protect. 74 (2011) 1852-1859.

146. K. Shannon, I. Phillips, J. Antimicrob. Chemother. 9 (1982) 91-102.

147. E. Culebras, J.L. Martinez, Front. Biosci. 4 (1999) D1-D8.

148. F.J. Schmitz, A.C. Fluit, M. Gondolf, R. Beyrau, E. Lindenlauf, J. Verhoef, H.P. Heinza, M.E. Jones, J. Antimicrob. Chemother. 43 (1999) 253-259.

149. S.B. Vakulenko, S. Mobashery, Clin Microbiol. Rev. 16 (2003) 430-450.

150. M.M. Alam, N. Kobayashi, M. Ishino, A. Sumi, K. Kobayashi, N. Uehara, N. Watanabe, Microb. Drug Resist. 11 (2005) 239-247.

151. J.Q. Ehrlich, Q.R. Bartz, R.M. Smith, D.A. Joslyn, P.R. Burkholder, Science 106 (1947) 417.

152. S. Schwarz, C. Kehrenberg, B. Doublet, A. Cloeckaert, FEMS Microbiol. Rev. 28 (2004) 519-542.

153. W.V. Shaw, Crit. Rev. Biochem. 14 (1983) 1-46.

154. W. Tao, M.H. Lee, J. Wu, N.H. Kim, J.-C. Kim, E. Chung, E.C. Hwang, S.-W. Leeb, Appl. Environ. Microbiol. 78 (2012) 6295-6301.

155. V.P. Syriopoulou, A.L. Harding, D.A. Goldmann, A.L. Smith, Antimicrob. Agents Chemother. 19 (1981) 294-297.

156. S. Soback, M.J. Paape, R. Filep, K.J. Varma, J. Vet. Pharmacol. Ther. 18 (1995) 413-417.

157. F. Schlünzen, R. Zarivach, J. Harms, A. Bashan, A. Tocilj, R. Albrecht, A. Yonath, F. Franceschi, Nature 413 (2001) 814-821.

158. I.A. Murray, W.V. Shaw, Antimicrob. Agents Chemother. 41 (1997) 1-6.

159. S. Horinouchi, B. Weisblum, J. Bacteriol. 150 (1982) 815-825.

160. S.J. Projan, J. Kornblum, S.L. Moghazeh, I. Edelman, M.L. Gennaro, R.P. Novick, Mol. Gen. Genet. 199 (1985) 452-464.

161. S. Schwarz, M. Cardoso, Antimicrob. Agents Chemother. 35 (1991) 1551-1556.

162. S. Schwarz, W.C. Noble, Lett. Appl. Microbiol. 18 (1994) 281-284.

163. P. Trieu-Cuot, G.de Cespedes, T. Horaud, Plasmid 28 (1992) 272-276.

164. V. Perreten, F. Schwarz, M. Boeglin, L. Cresta, G. Dasen, M. Teuber, Nature 391 (1998) 801-802.

165. C. Werckenthin, M. Cardoso, J.L. Martel, S. Schwarz, Vet. Res. 32 (2001) 341362.

166. P. Ayoubi, O. Kilic, M.N. Vijayakumar, J. Bacteriol. 173 (1991) 1617-1622.

167. S. Schwarz, C. Werckenthin, C. Kehrenberg, Antimicrob. Agents Chemother. 44 (2000) 2530-2533.

168. K.S. Long, J. Poehlsgaard, C. Kehrenberg, S. Schwarz, B. Vester, Antimicrob. Agents Chemother. 50 (2006) 2500-2505.

169. C. Kehrenberg, S. Schwarz, L. Jacobsen, L.H. Hansen, B. Vester, Mol. Microbiol. 57 (2005) 1064-1073.

170. K. Hiramatsu, H. Hanaki, T. Ino, K. Yabuta, T. Oguri, F.C. Tenover, J. Antimicrob. Chemother. 40 (1997) 135-136.

171. S. Gardete, A. Tomasz, J. Clin. Invest. 124 (2014) 2836-2840. 
172. B.P. Howden, J.K. Davies, P.D. Johnson, T.P. Stinear, M.L. Grayson, Clin. Microbiol. Rev. 23 (2010) 99-139.

173. A. Tomasz, S. Nachman, H. Leaf, Antimicrob. Agents Chemother. 35 (1991) 124129.

174. C. Liu, H.F. Chambers, Antimicrob. Agents Chemother. 47 (2003) 3040-3045.

175. D.R. Cameron, D.V. Ward, X. Kostoulias, B.P. Howden, R.C. Moellering Jr., G.M. Eliopoulos, A.Y. Peleg, J. Infect. Dis. 205 (2012) 1677-1687.

176. S. Gardete, C. Kim, B.M. Hartmann, M. Mwangi, C.M. Roux, P.M. Dunman, H.F. Chambers, A. Tomasz, PLoS Pathog. 8 (2012) e1002505.

177. M. Matsuo, L. Cui, J. Kim, K. Hiramatsu, Antimicrob. Agents Chemother. 57 (2013) 5843-5853.

178. M. Shoji, L. Cui, R. Iizuka, A. Komoto, H.M. Neoh, Y. Watanabe, T. Hishinuma, K. Hiramatsu, Antimicrob. Agents Chemother. 55 (2011) 3870-3881.

179. G. Sakoulas, G.M. Eliopoulos, V.G. Fowler Jr., R.C. Moellering Jr., R.P. Novick, N. Lucindo, M.R. Yeaman, A.S. Bayer, Antimicrob. Agents Chemother. 49 (2005) 2687-2692.

180. L. Cui, H.M. Neoh, M. Shoji, K. Hiramatsu, Antimicrob. Agents Chemother. 53 (2009) 1231-1234.

181. B.P. Howden, T.P. Stinear, D.L. Allen, P.D. Johnson, P.B. Ward, J.K. Davies, Antimicrob. Agents Chemother. 52 (2008) 3755-3762.

182. Y. Watanabe, L. Cui, Y. Katayama, K. Kozue, K. Hiramatsu, J. Clin. Microbiol. 49 (2011) 2680-2684.

183. M. Sievert, M.L. Boulton, G. Stoltman, D. Johnson, M.G. Stobierski, F.P. Downes, P.A. Somsel, J.T. Rudrik, W. Brown, W. Hafeez, T. Lundstrom, E. Flanagan, R. Johnson, J. Mitchell, S. Chang, MMWR Morb. Mortal. Wkly. Rep. 51 (2002) 565567.

184. D.M. Sievert, J.T. Rudrik, J.B. Patel, L.C. McDonald, M.J. Wilkins, J.C. Hageman, Clin. Infect. Dis. 46 (2008) 668-674.

185. P. Courvalin, Clin. Infect. Dis. 42 (2006) S25-S34.

186. W.C. Noble, Z. Virani, R.G. Cree, FEMS Microbiol. Lett. 93 (1992) 195-198.

187. M. Arthur, F. Depardieu, P. Reynolds, P. Courvalin, Mol. Microbiol. 21 (1996) 33-44.

188. M. Arthur, C. Molinas, F. Depardieu, P. Courvalin, J. Bacteriol. 175 (1993) 117127.

189. $\quad$ R. Leclercq, E. Derlot, J. Duval, P. Courvalin, N. Engl. J. Med. 319 (1988) 157161.

190. S. Handwerger, J. Skoble, Antimicrob. Agents Chemother. 39 (1995) 24462453.

191. S. Saadat, K. Solhjoo, M.-J. Norooz-Nejad, A. Kazemi, Oman Med. J. 29 (2014) 335-339.

192. R. Quintiliani Jr., P. Courvalin, FEMS Microbiol. Lett. 119 (1994) 359-363.

193. R. Patel, J.R. Uhl, P. Kohner, M.K. Hopkins, J.M. Steckelberg, B. Kline, F.R. Cockerill, Antimicrob. Agents Chemother. 42 (1998) 202-205.

194. K.H. Dahl, G.S. Simonsen, O. Olsvik, A. Sundsfjord, Antimicrob. Agents Chemother 43 (1999) 1105-1110.

195. M. Arthur, F. Depardieu, P. Reynolds, P. Courvalin, Mol. Microbiol. 21 (1996) 33-44.

196. M.J. Rybak, E. Hershberger, T. Moldovan, R.G. Grucz, Antimicrob. Agents Chemother. 44 (2000) 1062-1066. 
197. E. Cercenado, F. Garcia-Garrote, E. Bouza, J. Antimicrob. Chemother. 47 (2001) 77-81.

198. D.M. Livermore, J. Antimicrob. Chemother. 51 (2003) ii9-ii16.

199. K.S. Long, B. Vester, Antimicrob. Agents Chemother. 56 (2012) 603-612.

200. S. Tsiodras, H.S. Gold, G. Sakoulas, G.M. Eliopoulos, C. Wennersten, L. Venkataraman, R.C. Moellering Jr., M.J. Ferraro, Lancet 358 (2001) 207-208.

201. Y. Song, Y. Lv, L. Cui, Y. Li, Q. Ke, Y. Zhao, J. Glob. Antimicrob. Resist. 8 (2017) 15.

202. C.A. Arias, M. Vallejo, J. Reyes, D. Panesso, J. Moreno, E. Castañeda, M.V. Villegas, B.E. Murray, J.P. Quinn, J. Clin. Microbiol. 46 (2008) 892- 896.

203. G.E. Zurenko, B.H. Yagi, R.D. Schaadt, J.W. Allison, J.O. Kilburn, S.E. Glickman, D.K. Hutchinson, M.R Barbachyn, S.J. Brickner, Antimicrob. Agents Chemother. 40 (1996) 839-845.

204. W.R. Miller, A.S. Bayer, C.A. Arias, Cold Spring Harb. Perspect. Med. 6 (2017) doi:10.1101/cshperspect.a026997.

205. J.M. Munita, A.S. Bayer, C.A. Arias, Clin. Infect. Dis. 61 (2015) S48-S57.

206. R.H. Baltz, Curr. Opin. Chem. Biol. 13 (2009) 144-151.

207. L. Dortet, N. Anguel, N. Fortineau, C. Richard, P. Nordmann, Int. J. Infect. Dis. 17 (2013) e1076-e1077.

208. A.S. Lee, B. Huttner, S. Harbarth, Infect. Dis. Clin. North Am. 25 (2011) 155-179.

209. X.X. Ma, T. Ito, C. Tiensasitorn, M. Jamklang, P. Chongtrakool, S. Boyle-Vavra, R. S. Daum, K. Hiramatsu, Antimicrob. Agents Chemother. 46 (2002) 1147-1152.

210. X.X. Ma, D.D. Sun, S. Wang, M.L. Wang, M. Li, H. Shang, E.H. Wang, E.J. Luo, Diagn. Microbiol. Infect. Dis. 70 (2011) 22-30.

211. F. Moreno, C. Crisp, J.H. Jorgensen, J.E. Patterson, Clin. Infect. Dis. 21 (1995) 1308-1312.

212. L. Archibald, L. Phillips, D. Monnet, J.E. McGowan, F. Tenover, R. Gaynes, Clin. Infect. Dis. 24 (1997) 211-215.

213. J. Merrer, F. Santoli, C. Appere de Vecchi, B. Tran, B. De Jonghe, H. Outin, Infect. Control Hosp. Epidemiol. 21 (2000) 718-723.

214. N. van de Sande-Bruinsma, H. Grundmann, D. Verloo, E. Tiemersma, J. Monen, H. Goossens, M. Ferech, Emerg. Infect. Dis. 14 (2008) 1722-1730.

215. Z. Koçak-Tufan, H. Irmak, C. Bulut, S. Cesur, S. Kinikli, A.P. Demlröz, Mikrobiyol. Bul. 46 (2012) 236-246.

216. M. Pujol, C. Peña, R. Pallares, J. Ariza, J. Ayats, M.A. Dominguez, F. Gudiol, Am. J. Med. 100 (1996) 509-516.

217. A. Gleeson, P. Larkin, C. Walsh, N. O'Sullivan, Palliat. Med. 30 (2016) 374-381.

218. S.M. Mandal, A.K. Ghosh, B.R. Pati, Am. J. Infect. Control. 43 (2015) e87-e88.

219. A.S. Haddadin, S.A. Fappiano, P.A. Lipsett, Postgrad. Med. J. 78 (2002) 385-392.

220. R.M. Klevens, M.A. Morrison, J. Nadle, S. Petit, K. Gershman, S. Ray, L.H. Harrison, R. Lynfield, G. Dumyati, J.M. Townes, A.S. Craig, E.R. Zell, G.E. Fosheim, L.K. McDougal, R.B. Carey, S.K. Fridkin, JAMA 298 (2007) 1763-1771.

221. R. Dantes, Y. Mu, R. Belflower, D. Aragon, G. Dumyati, L.H. Harrison, F.C. Lessa, R. Lynfield, J. Nadle, S. Petit, S.M. Ray, W. Schaffner, J. Townes, S. Fridkin, JAMA Intern. Med.173 (2013) 1970-1978.

222. K.T. Kavanagh, S. Abusalem, L.E. Calderon, Antimicrob. Resist. Infec. Control 6 (2017) 34. doi 10.1186/s13756-017-0193-0.

223. A. Tomasz, S. Nachman, H. Leaf, Antimicrob. Agents Chemother. 35 (1991) 124129. 
224. B.J. Hartman, A. Tomasz, J. Bacteriol. 158 (1984) 513-516.

225. H. de Lencastre, I. Cuoto, I. Santos, J. Melo-Cristino, A. Torres-Pereira, A. Tomasz, Eur. J. Clin. Microbiol. Infect. Dis. 13 (1994) 64-73.

226. T. Ito, Y. Katayama, K. Hiramatsu, Antimicrob. Agents Chemother. 43 (1999) 1449-1458.

227. X.X. Ma, T. Ito, P. Chongtrakool, K. Hiramatsu, J. Clin. Microbiol. 44 (2006) 4515-4527.

228. F.F. Martineau, F.J. Picard, N. Lansac, C. Menard, P.H. Roy, M. Ouellette, M.G. Bergeron, Antimicrob. Agents Chemother. 44 (2000) 231-238.

229. G. Adwan, K. Adwan, N. Jarrar, A. Amleh, Rom. Arch. Microbiol. Immunol. 73 (2014) 9-18.

230. EFSA (European Food Safety Authority). The European Union summary report on antimicrobial resistance in zoonotic and indicator bacteria from humans, animals and food in 2015. EFSA Journal 15 (2017) 1-212.

231. CLSI (Clinical and Laboratory Standards Institute). Performance standards for antimicrobial disk susceptibility tests; Approved standard - twelfth edition. Document M02-A12, 2015, Wayne, USA, pp. 73.

232. CLSI (Clinical and Laboratory Standards Institute). Methods for dilution antimicrobial susceptibility tests for bacteria that grow aerobically; Approved standard - tenth edition. Document M07-A10, 2015, Wayne, USA, 87 pp.

233. World Health Organization Antibiotic resistance Fact sheet Updated November 2017 http://www.who.int/mediacentre/factsheets/antibiotic-resistance/en/ (Feb 25, 2018).

234. M. Karni, D. Zidon, P. Polak, Z. Zalevsky, O. Shefi, DNA Cell Biol. 32 (2013) 1-4.

235. C. Faria, I. Vaz-Moreira, E. Serapicos, O.C. Nunes, C.M. Manaia, Sci. Total Environ. 407 (2009) 3876-3882.

236. T. Schwartz, W. Kohnen, B. Jansen, U. Obst, FEMS Microbiol. Ecol. 43 (2003) 325-335.

237. M.T. Wan, C.C. Chou, Water Res. 64 (2014) 288-295.

(C)2018 by the authors; licensee IAPC, Zagreb, Croatia. This chapter is an open-access publication distributed under the terms and conditions of the Creative Commons Attribution license (http://creativecommons.org/licenses/by/3.0/) (cc)) EY 